\title{
Impact of Land-Use and Climate on Biodiversity in an Agricultural Landscape
}

\author{
Andrzej Kędziora, Krzysztof Kujawa, Hanna Gołdyn, Jerzy Karg, \\ Zdzisław Bernacki, Anna Kujawa, Stanisław Bałazy, Maria Oleszczuk, \\ Mariusz Rybacki, Ewa Arczyńska-Chudy, Cezary Tkaczuk, \\ Rafał Łęcki, Maria Szyszkiewicz-Golis, Piotr Pińskwar, \\ Dariusz Sobczyk and Joanna Andrusiak
}

Additional information is available at the end of the chapter

http://dx.doi.org/10.5772/48653

\section{Introduction}

The term "biodiversity" was used for the first time by wildlife scientist and conservationist [1] in a lay book advocating nature conservation. The term was not adopted by more then decade. In 1980 use of the term by Thomas Lovejoy in the Foreword to the book "Conservation Biology" [2] credited with launching the field of conservation biology introduced the term to the scientific community. There are many definitions of biodiversity. One of them, formulated in Millennium Ecosystem Assessment [3] reads: " Biodiversity is the variability among living organisms from all sources, including terrestrial, marine, and other aquatic ecosystems and the ecological complexes of which they are part; this includes diversity within species, between species, and of ecosystems". Biodiversity forms the foundation of the vast array of ecosystem services that critically contribute to human well-being. Biodiversity is important in human-managed as well as natural ecosystems. Decisions humans make that influence biodiversity affect the well-being of themselves and others [3].

Biodiversity is the one of basic driving forces which influence and determine most of ecosystem services [3]. Interdisciplinary and long-term (50 years) researches carried out by Institute for Agricultural and Forest Environment were focused on recognition of factors, that brought about impoverishment of biodiversity in agricultural landscape and finding the ways to counteract these negative changes. During a few last centuries the rapid decrease of biodiversity has been observed all over the world [4]. Human activity brought to worsening 
the habitat ability to ensure the conditions for living rich plant, animal and fungi population. Conversion of more stable ecosystems like forests, meadows, and wetlands into less stable ones like arable land causes increase of threats to such fundamental processes like energy flow and cycling of matter in the environment [5]. Such factors like climate changes, simplification of landscape structure and changes in farming practices have resulted in worsening habitat conditions (water conditions, environment pollution, soil degradation etc.) leading in consequence to impoverishment of biodiversity. Agriculture is commonly considered to be one of the main threats to the biological diversity. Farmers try to eliminate all organisms which could diminish crops to increase agricultural production. In order to channel the solar energy and nutrients into products useful for man, farmers simplify plant cover structure both within cultivated fields (selection of genetically uniform and productive cultivars, elimination of weeds), and within agricultural landscape (eradication of hedges, patches of trees, mid-field wetlands and ponds, riparian vegetation strips). Increasing usage of fertilizers and pesticides caused environmental pollution that threats all organisms. Apart from this, the unfavorable climate changes were observed during the last century. Increase of air temperature and wind speed without clear increases of precipitation brought about worsening water conditions.

The agricultural landscape located in Wielkopolska (western Poland) around the Turew village (currently protected by law as landscape park) is a distinct example of such management which allows keeping intensive crop production without causing serious degradation of habitat and impoverishment of biodiversity. A network of diverse linear habitats (shelterbelts, hedgerows, roadside verges, tree alleys etc.) and small wood patches established 200 years ago, stretches of meadows, small mid-field water reservoirs, or wetlands provide good refuge for many organisms and unique facility for studying the effects of farming intensification at stable spatial arrangement of non-farmed habitats. In the Turew agricultural landscape near 850 species of vascular plants, 2600 insect species, 120 species of breeding birds, and about 700 species of macrofungi were detected, including many woodland species, as well as a variety of invertebrates including rare, threatened, protected by law and umbrella species [6]. As many, as $60-100 \%$ of animal taxa showed by regional lists of taxa live in this agricultural landscape.

The crucial factor for maintenance numerous and favorable habitats for various groups of animals is well developed structure of landscape. Guidelines for shaping of landscape structure towards ensuring maintenance end enhancement biodiversity as a crucial factor for sustainable development of agricultural landscape. For instance, such elements of landscape like shelterbelts, hedges, and strips of meadows, allows to survive animals (like bees), which population is reduced in the result of intensive use of pesticides. The old trees with a lot of hollows, existing within shelterbelts, are necessary for keeping rich population of many species of birds. In the chapter we summarized our knowledge on quantitative relationships between landscape features and diversity (species richness and abundance) of taxa mentioned above and to present the spatio-temporal pattern of species distribution and their abundance. 
It is possible to reconcile very high level of intensive agriculture with protection and even enhancement of biodiversity. Creating a very mosaic landscape (biotic and abiotic component of landscape) is a toolkit for solving this problem. The integrity of biological and physical or chemical processes is a basic foundation of modern ecosystem or landscape ecological approaches. Recognition of this functional relationships leads to the conclusion that biodiversity cannot be successfully protected only by isolation from hostile surrounding, but its conservancy should rely on the active management of the landscape structures in a direction of their diversification. The very important guidelines for enhancement of sustainable system resistance and resilience to threats are diversification of its structure Generally speaking, the results of our study are in line with very recent findings, that due to the great diversity of climatic and physiographic conditions as well as customary regulatory and management of the landscape across Europe, makes it very much needed regional approach to biodiversity protection and management. For example, application of agri-environmental schemes, with the rules elaborated mostly in Western Europe (where agricultural landscape is in general extremely simplified, and where climate is mild, e.g. winters are warmer) to CEE countries seems to be inaccurate $[7,8]$.

\section{Description of Study areas (Turew mosaic landscape and Kościan Plain)}

The "Turew Mosaic Landscape" in this chapter is the part of the larger study area called "Kościan Plain" is located about $40 \mathrm{~km}$ south from Poznań - the capital of Wielkopolska region and its geographical coordinates are $16^{\circ} 45^{\prime}$ to $17^{\circ} 05^{\prime} \mathrm{E}$ and $51^{\circ} 55^{\prime}$ to $52^{\circ} 05^{\prime} \mathrm{N}$ (Figure 1 ). The Field Station of Institute is situated in the middle of the landscape near a small village called Turew. Therefore, the name Turew is used to identify the landscape. Wielkopolska region is known as the "bread basket". Agriculture is the dominant activity of the region.

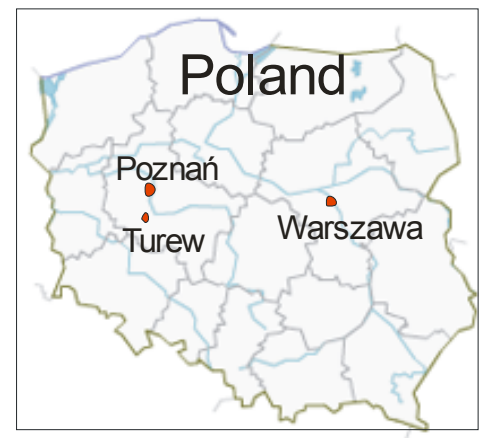

Figure 1. Location of Turew Landscape

The study area "Kościan Plain" (area about $200 \mathrm{~km}^{2}$ ) is located within radius of $5-10 \mathrm{~km}$ around Turew, in the area of the West Polish Lowland, which is a ground moraine created during the Baltic glaciation, that terminated about 10000 year ago. Although the differences in altitude are small (from $75 \mathrm{~m}$ to $90 \mathrm{~m}$ a.s.l.) and the area consists of a rolling plain made 
up of slightly undulating ground moraine there are many drainage valleys. In general, light textured soils (Hapludalfs, Glossudalfs and less frequently met Udipsamments) with favorable water infiltration conditions are found in uplands. Deeper strata are poorly permeable and percolating water seeps to valleys and ditches or main drainage canal. In depressions Endoaquolls, poorly drained, collect water runoff and discharge water to surface drainage system [9].

The climate of the region is shaped by the conflicting air masses from the Atlantic, Eastern Europe and Asia (arctic 6\%, polar martitime 59\%, polar continental 28\%, tropical 7\%), which are modified by strong Arctic and Mediterranean influences. It results in a great changeability of weather conditions and the predominance of western winds brings strong oceanic influence that manifest in milder winters and cooler summers in comparison to the centre and east of Poland. Within Poland, this area is one of the warmest, with an annual mean temperature above $8^{\circ} \mathrm{C}$ (range from 6.9 to $8.5^{\circ} \mathrm{C}$ ). Mean annual global radiation amounts $3700 \mathrm{MJ} / \mathrm{m}^{2}$ and, mean annual net radiation equals to $1315 \mathrm{MJ} / \mathrm{m}^{2}$.

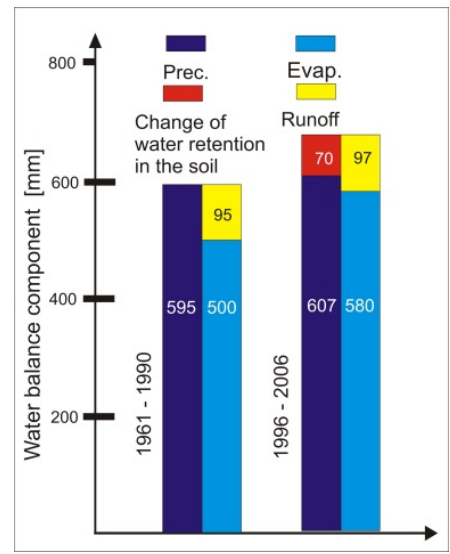

Figure 2. Water balance in Wielkopolska in 1961 - 1990 reference period and In 1996-2006 warm and dry period

Thermal conditions existing in the Turew landscape are favorable for cultivated plant growth. The mean plant growth season with temperatures above $5^{\circ} \mathrm{C}$ lasts from $21 \mathrm{March}$ till 30 October. In reference 1961 - 1990 period (Figure 2) the mean annual precipitation is equal to $595 \mathrm{~mm}$, of which $365 \mathrm{~mm}$ falls between April-September, and $230 \mathrm{~mm}$ in the period of October-March. Although the amount of precipitation in the spring-summer period is higher than in autumn and winter, a shortage of water occurs frequently in the plant growth season. This situation is aggravated by the dominance of light soils with poor water storing capacities. Average annual evapotranspiration amounts to $500 \mathrm{~mm}(485 \mathrm{~mm}$ in whole country) and water runoff is equal to $95 \mathrm{~mm}$ (212 $\mathrm{mm}$ in whole country). But in warm and dry period of 1996 - 2006 evapotranspiration was as high as $580 \mathrm{~mm}$, which resulted in decreasing water retained in soil by $70 \mathrm{~mm}$. It caused worsening of water conditions for plants. 
In the land-use structure of whole catchment arable land makes $62.2 \%$, forests and shelterbelts (mid-field rows of trees) cover $17.9 \%$, meadows and pastures $12.5 \%$, water bodies $3.5 \%$, and villages, roads the rest of the area. There are no industrial facilities. The mean density of inhabitants equals to 55 individuals per $1 \mathrm{~km}^{2}$.

- The natural forest complexes were replaced by woods planted by man or converted into cultivated fields that constitute up $70 \%$ of the total area, shelterbelts and small forests 16 $\%$ and grasslands $9 \%$.

- The structure of crops at the beginning of the 21 century was as follows: cereals (mainly, wheat and Triticale) including maize made $76.7 \%$, vegetables $16 \%$, potato, seed-rape, and sugar beets $6 \%$.

The specific landscape of Turew neighborhood located in Wielkopolska was shaped during the twentieths of XIX century by general D. Chłapowski who farmed on 10 thousands hectares. He introduced essential changes in farming system as well as in the field today called landscape engineering. Conversion of the open and uniform agricultural landscape in mosaic which is rich in stable element like shelterbelts small mid-field water reservoirs was the results of his activity. Many wooded patches, shelterbelts, tree lines, clumps of trees were planted in the landscape. They were designed as a shelter for domestic animals and the measures against wind erosion. Since 1950s last century the investigation of agricultural landscape functioning has been carried out within that areas. About of one hundred $\mathrm{km}$ of linear and 10 hectares of new shelterbelts and woody patches were planted during the two last decades.

The "Turew Mosaic Landscape" (Figure 3A) is still abundant in various wooded patches located in upland parts of the landscape or along banks of the drainage water system as well as along other non-crop habitats, such as small water reservoirs, marshy habitats, bounds and so on. All together there are more than 800 shelterbelts forming the network in an area of 17200 ha. Cultivated fields make $70 \%$ of the total area, forests and shelterbelts $-16 \%$ and grasslands $-9 \%$. The majority of farms are small. Only $27 \%$ are larger than 10 ha.

Comparative studies have been carried out in uniform agricultural landscape (Figure 3B) composed of large fields located about $10 \mathrm{~km}$ apart characterized by the same climatic conditions and similar soil types. This uniform landscape is almost entirely devoid of shelterbelts and the drainage system is mostly operating as an underground system. The cultivated fields are bigger than those in the mosaic landscape, and are ranging from 15 to 150 ha. A similar crop structure is appears in both mosaic and uniform landscape. The structure of the crops at the end of 1990s was as follows: cereals $(68.1 \%)$, maize $(9.6 \%)$, vegetables $(16 \%)$, potatoes, seed-rape and sugar beets $(6 \%)$. The substantial increase of cereal cultivations were observed over the period of 1984-2004. In 1985 cereals covered $48.1 \%$ of total arable land, in 1997 their contribution increased to $63.5 \%$ and in 2002 cereals were cultivated on $73.9 \%$ of arable land. Among the cereals wheat and triticale cultivations dominated. 


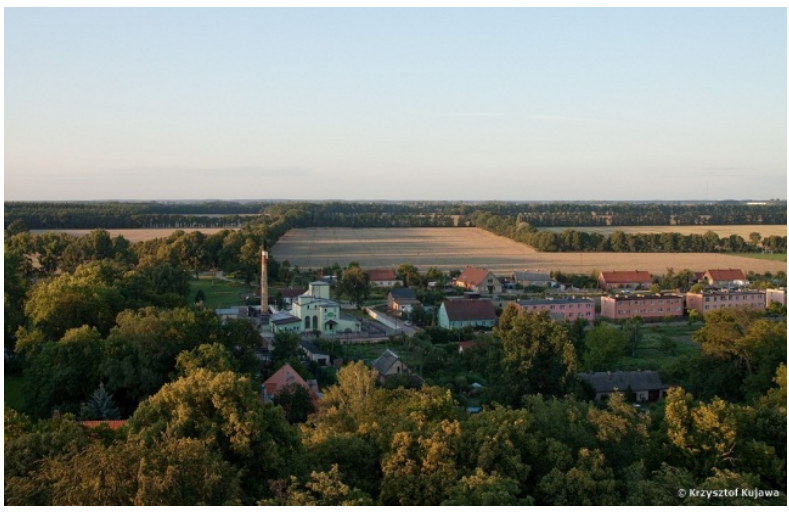

(a)

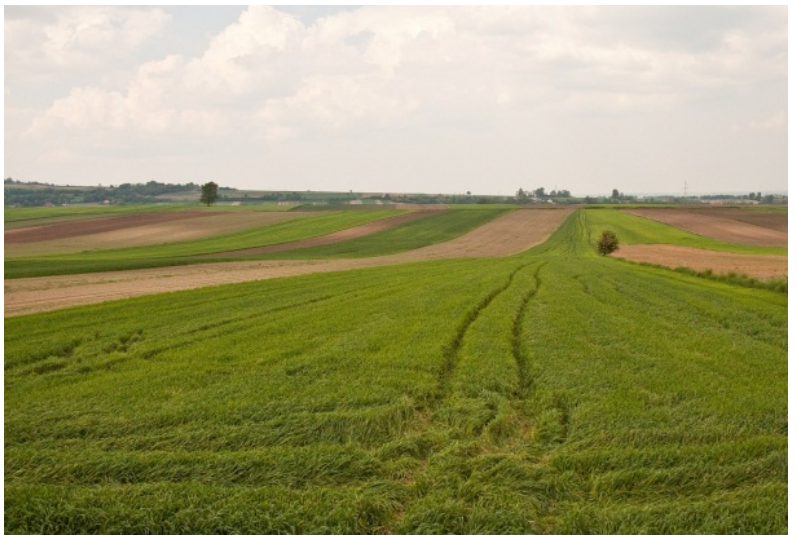

(b)

Figure 3. A. Mosaic landscape. Phot. K. Kujawa; B. Uniform landscape. Phot. K. Kujawa

\section{Methods}

Due to a great variety of biological and ecological features of studied taxa, their distribution, abundance and diversity patterns were studied with the use of many methods differing strongly between the taxa. Diverse goals of former research projects carried out in the area described above involved various scales (approximately from hectares to tens of hundred square kilometers) and diverse habitats. Generally speaking, we refer our results mostly to three different objects:

a. landscape in broad sense (ca. $200 \mathrm{~km}^{2}$, called in the chapter "Kościan Plain"), i.e. comprising all found habitat types, such as crop fields, meadows, semi-natural grasslands, woodlands, small wooded clumps (tree or shrub lines, belts or clumps), wetlands, roadside verges, water bodies and courses, 
b. agricultural land in narrow sense (ca. $20 \mathrm{~km}^{2}$, called "Turew Mosaic Landscape"), i.e. consisted of cultivated fields, meadows and grasslands, field margins (with all kinds of plant cover, roadside verges etc.), drainage ditches, small wooded patches, small water bodies and courses,

c. habitats (with area of tens hectares), called just wheat field, arable land, small wooded patches, drainage ditches, etc.

In other cases, described object (piece of landscape other than "Kościan Plain" and "Turew Mosaic Landscape") is described separately to distinguish it from the above listed. During the data analyzing, various statistical tests and procedures were applied, which are cited in appropriate place with commonly used names (t-test, Mann-Whitney test, Wilcoxon test, Analysis of Variance - ANOVA, Principal Component Analysis - PCA, General Linear Model - GLM, etc.). The significance level used for all tests was 0.05. For estimation total bird species richness, the Jack-Knife 2 estimator was used [10]. Arythmetic mean is given with standard deviation (SD).

\subsection{Plants}

Studies on spontaneous flora of the "Kościan Plain" have been carried out since 1975. First they were collected mainly in aquatic and marsh ecosystems and only occasionally apart from them. From 2000 they included the entire landscape and were taken with the method of mapping of all the species in the network of equal basic fields. Lists of the plant species of every investigated plot were analyzed. Material for the study on relationships between the floristic diversity of agricultural landscape and the diversity of its structural elements was collected on 37 square plots ( $1 \mathrm{~km}^{2}$ each) [11]. Landscape diversity was assessed by number of elements of landscape (i.e. spatial units that differ in land use).

The most important measures used in floristic research include: species richness, floristic distinction (i.e. mean coefficient of species rarity), number of environmentally valuable species (recessive i.e. declining species, species included in red lists for Poland or Wielkopolska, protected species, and those rare regionally and locally), sociological groups, and geographic-historical groups. The status of species in the flora follows reports on Polish and regional floras. To diagnose the sociology of the taxa [12] elaboration was used. Names of alien geographic-historical groups follow [13,14]. Those are: archaeophytes (naturalized alien species introduced before ca. 1,500), naturalized neophytes (naturalized alien species introduced after ca. 1,500) and casual neophytes (casual alien species introduced after ca. 1,500 occurring sporadically or for a short time within the studied area). Among native species nonsynanthropic spontaneophytes (species which do not show permanent trends in occupying transformed anthropogenic habitats) and apophytes (indigenous species, permanently occupying strongly transformed anthropogenic habitats) are distinguished according to [15]. Species names follow [16].

Field inventory work on dendroflora was carried out during vegetative periods from 2001 to 2003. Prior to field work there were preparatory work on maps and aerial photos conducted. The inventory and evaluation encompassed all wooden plants assembles of open landscape, 
the area of which was smaller than 5 ha: shelterbelts, woodlots, avenues, tree lines and hedgerows. Desk work, which followed the field survey, was aimed at evaluation of wooden flora located in different landscape context among other by number of species and share of native and alien species [17].

The study of the flora and plant associations in the lake Zbęchy, peat bogs and Wyskoć Canal were carried first in 1976-1979. They were repeated in 2006-2007 [18 - 21]. Between these periods occasional studies were still performed. The commonly used Braun-Blanquet method was applied. The associations were distinguished and the taxonomy of syntaxa was adopted after [22]. The data for both investigated seasons were compared and valorized regarding to they threat and frequency of occurence according to [22] elaboration. The same method was used in the research on the flora of ponds that started in 1985 [23].

\subsection{Insects}

The basic apparatus (called "biocenometer" - Figure 4) used in the study of above-ground entomofauna in vegetation season is composed of cap in the form of a truncated pyramid with trapping surface $50 \times 50 \mathrm{~cm}$ and height $70 \mathrm{~cm}$. It is randomly barraged on the study area and trapped invertebrates are taken by suction apparatus, powered by a generator [24]. In all years (from 1970s till now) and habitats (crop fields, meadows, small wooded areas) the samples were collected with a frequency no less than three samples during one season (usually monthly, from May to October), in the series including 10 samples along a transect located in a given sample plot (habitat studied). Samples were separated by hand and the gained material was stored dried and identified to families (all insects) or genus and species (some groups of insects)[25].

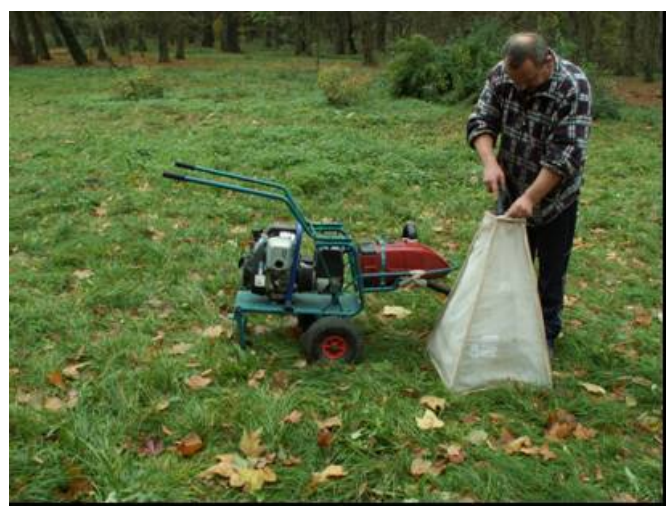

Figure 4. Biocenometer. Phot. J. Karg.

The samples of insects wintering in litter and soil were taken from 1990s till now in shelterbelts and on adjacent crop fields. As many as 10 soil monoliths (without litter) with dimensions 10x10x10 cm were taken in each series three times per winter. Soil was manually separated. Obtained material was preserved in $75 \%$ alcohol and identified to the level of 
family or order (some larvae and pupae). Simultaneously, on the same dates and on the same places, litter samples from the shelterbelts were collected. Frames with dimensions $25 \times 25 \mathrm{~cm}$ were used, and 20 samples were taken in each series. Further procedures were the same as in the case of soil samples.

The butterflies were studied mostly with the use of a transect method [26]. Eleven transects (with total length of $10.25 \mathrm{~km}$ ) were located along the roads adjacent to various habitats (wooded areas, crop fields and meadows, young shelterbelts etc.) and the butterflies were usually counted and identified to species level in $5 \mathrm{~m}$ wide belt. The gathered data were used for the estimation of total or species abundance index estimation.

Since beginning of 1960s the observation of nocturnal butterflies were carried out using light trap method.

\subsection{Spiders}

Spider communities in winter cereals, sugar beet and alfalfa crops were studied in two types of agricultural landscape within the "Kościan Plain": mosaic one with the net of shelterbelts and the uniform one with lack of shelterbelts, where the majority of the terrain is covered by large sized crop fields. The results obtained from three fields in each landscape within three years were compared. To recognize an effect of wooded habitats on spider community occurring in crop fields, the spiders were collected in the distances of $10 \mathrm{~m}, 50 \mathrm{~m}$ and $100 \mathrm{~m}$ from shelterbelts (in case of mosaic landscape) or from a road (in case of uniform landscape). To assess the spider density, the samples were taken with biocenometer twice a year (in May and July). Foliage-dwelling spiders were taken by sweet-netting (50 sweeps were a sample), 2-3 times per season (from April to September).

\subsection{Fishes}

The results have been obtained by using an electrofishing method with IUP-12 device [27], used for catching fish in Wyskoć Canal. The most recent data were gathered in two $100 \mathrm{~m}$ long sections of this water course in 2007 and earlier - in 1997-1999 in $1000 \mathrm{~m}$ long section. The information on Zbęchy Lake was obtained from the user (Polish Angling Association, the Fishing Company in Osieczna).

\subsection{Amphibians}

Investigations of amphibians were carried out in the "Kościan Plain" mostly in the years 1995-2000, since March to October. Investigation covered mainly reproducing amphibian populations as well as water bodies in the spring because amphibians aggregate there for reproduction. The first step was cartographical analysis of the study area on the basis of topographic maps (1:10000) and aerial photographs. Then, location of ponds and all wet areas was checked in the field. As many as 150 water reservoirs were found. They were divided into 4 types, depending on impact of man activity: village ponds (located up to 100 $\mathrm{m}$ from buildings), reservoirs located on the meadows, in the fields and in the forests. In each water body the number of species and its abundance were studied. The presence of 
species was verified on the basis of direct observations of adults, juveniles or tadpoles. In some cases voices of males or unique characters of egg deposits were taken into account. Abundance of populations was estimated on the basis of direct observations of adults, counting of male voices during their high vocal activity (at night only) and numbers of egg clumps (for the brown frogs Rana temporaria and Rana arvalis only). The threats to amphibians (pollution, presence of fishes, ducks) were identified for each water body. Each reservoir was classified with respect to its usefulness to amphibian breeding (type of water plants, grade of shading, depth etc.). Moreover, in 32 reservoirs some chemical features of water $(\mathrm{pH}$, ammonium, nitrates, and phosphates) were analyzed [28, 29].

\subsection{Birds}

At first, it is worth to mentioning that during the study species diversity in heterogenic habitat or landscape, serious methodological problem is defining the "representative" both study area and sampling effort. In case of birds, the representative agricultural landscape was defined as a mosaic of cultivated fields, meadows, pastures and small wooded area with the area not exceeding 4 ha and it was located in the "Turew Mosaic Landscape". To control biases related to sampling effort and to avoid formulation of biased conclusions, we applied here triple approach: a) description of species richness, b) comparisons to other comparable data in Poland, c) analysis of species richness indicators.

The distribution and population density of birds was studied with the aid of a variety of techniques, depending on the goal for a given research project.

a. Most data have been gathered with the use of a combined version of cartographic methods [30], which was used in 1964-66, 1984, and since 1988 till now (with some time gaps). In all cases (plots and years) at least 6 counts/per plot were done (in most years 9 counts) and number of breeding pairs was established on the basis of "paper territories" (clumps of at least 3 records of territorial males) or other observations of breeding behavior. The method was applied in all kinds of small wooded areas clumps of trees, tree alleys and tree belts (in total of ca. 100 plots) as well as in few fragments of open landscape.

b. Transect method [31] was used for recognition of bird community patterns in an open landscape, among others for assessment of red fox impact on distribution and abundance of birds. The birds were censused on 200-300 m wide transects (several tens $\mathrm{km})$, in the morning, twice a breeding season.

c. Point count methods [31] was applied when relationships between landscape structure and birds abundance and species richness had been studied in scale of tens of square kilometers (hundred points). Birds were counted twice a breeding season in the morning, up to 100 or $150 \mathrm{~m}$ from place of standing.

In next step, for understanding the effect of environmental factors on the bird communities in space and time, habitat structure was quantified with the aid of several variables in three scales: within the plot (tree belt, tree clump etc.), in close neighborhood (adjacent area) and in landscape around a plot (i.e. within a radius of $1500 \mathrm{~m}$ from given wooded patch). 
a. Within the plot: tree, shrub, herb percentage cover, tree stem density, tree and shrub species diversity etc. [32, 33].

b. Area adjacent to studied plots : crop diversity, crop patch density etc. [33].

c. Landscape: woodiness index, percentage cover of crop fields, density of ecotones etc. [33].

In the next step the number of independent variable was reduced with the aid of PCA if needed, and the relationships between habitat or landscape structure were verified with the use of a various regression models.

\subsection{Mammals}

Small mammals were studied in 1999-2001 in two shelterbelts of different age located in crop fields in the "Turew Mosaic Landscape". The young one (16 m wide) was planted in autumn 1993 year and consisted of oaks, pines, birches, poplars, elms, maples, beeches and some other species in addition. The old one (36 m wide) was created with the shelterbelts' network in XIX century. The tree stand consisted of false acacia (with admixture of several oaks). Catch-Mark-Release (CMR) method was used. Traps were located in consistent lay out in both studied shelterbelts. 16 transects each 20 meters were set, 4 points including 2 traps were located in each transect. The traps were inspected every morning for 10 days within each season series (spring, summer, autumn).

In former years also other groups of mammal were studied. Carnivores were studied with trapping (small mustelids), recording of burrows and snow tracking. Night counting (with searchlight attached to a car) was also used. Belt assessment method with a line of beaters moving through selected area was used for estimation of hares. Roe deer and wild boar were counted by direct observation in late winter and early spring seasons [34].

\subsection{Macrofungi}

The study on macrofungi species diversity in the "Kościan Plain" was carried out basically with the use of three methods :

1. Route methods, enabling a basic (rough) recognition of species diversity in a large area.

2. Permanent plots, allowing for detailed description of fungal communities in various habitat types as well as for making comparison between the communities.

3. Transect method, which enables gathering the information from relatively large areas, comparing between them and detecting changes in species richness and diversity in a various ecosystems.

Additionally, in 2000-2003 study was carried out in 50 permanent plots (area of 400m²) located in managed forests, village parks, road tree alleys, tree belts and clumps of trees.

The route method has been used systematically since 1997 in various habitats. The rate of colonization of windbreak introduced in arable field is studied from 1998 [35], and preliminary study on the mycobiota of ephemeral habitats characteristic for a Polish 
lowland agricultural landscape (manure and straw piles) are realized from 2009. In result, in 1997-2010 numerous data on species diversity of a fragment of agricultural landscape have been collected.

\subsection{Microfungi}

Due to specificity of biological features of fungal pathogens, i.e. demanding special research techniques, the study was designed and carried out in other way than previously described taxa. The study of the fungal pathogens (infecting insects (Insecta), true spiders (Araneae) and mites (Acari)) was aimed at (1) recognition of their real resources and diversity in particular habitats, (2) - estimation of their effects on noxious and beneficial arthropod populations. They were conducted in German, France, and Poland during 10 vegetation seasons (1995-2004) in agroecosystems and neighboring forests. In agroecosystems three groups of elements were studied: annual crops (cereals and row plants), perennial crops (including meadows and pastures) and non-farmed clumps or strips of wild vegetation, including rushes and arborescent plants. This allowed for synthesis of the results for simplified (uniform) and diversified (mosaic) landscape types. The cases of epizootic appearance of particular pathogens' species were treated with special attention independently on the noxiousness or usefulness of their host species [36]. Before undertaking the extended studies in three countries, the methods were elaborated and tested in the "Kościan Plain" and the Wielkopolski National Park - both in the central Wielkopolska region (Poland). Both these areas have been included into the referred researches.

The sample plots were located along transects running across a chosen landscape fragments differing in plant cover, habitat structure or/and human impact. Material from 3-5 randomly scattered sample plots $(2 \times 2 \mathrm{~m})$, where plant cover up to the height of $2.5 \mathrm{~m}$ and the litter including superficial layer of soil was carefully searched, served as basic samples [37]. The invertebrates were sampled two times during every growing season - in the turns of spring/summer and summer/autumn. Additional checking searches were made in other dates, but only in Poland. The applied methods give the best results in the recognition, sampling, and species isolation of these pathogens group, often allowing to discover spatial distribution of epizootic appearance and new species for science.

Apart from the study on pattern of occurrence, for some habitats and countries the investigations on the pathogens of the subcortical and wood-boring insects were carried out. Mortality causes of these insects - together with associated with them invertebrates in their feeding sites - have been investigated by the immediate stereo-microscopic searches of samples from invaded trees (logs and branches) and laboratory rearing of them, for periodical isolation of appearing pathogens [38, 39].

Occurrence and diversity of entomopathogenic fungi in the soil from different habitats of agricultural landscape, including the "Turew Mosaic Landscape" and closely situated Farm Karolew applying no-tillage system have been investigated in th period 1996 - 2006. In total 
296 soil samples from 74 locations in Poland were collected in the years 1996-2006 mainly from agrocenoses (arable fields, meadows, pastures), semi-natural biotopes (shelterbelts, mid-field afforestations, balks) and forest biotopes. Fungi were isolated from soil samples by means of the "Galleria bait method" [40] and selective agar medium [41]. The infective potential of particular soil samples has been related to the mean colony forming units (CFU) (colony forming units) per $1 \mathrm{~g}$ of checked soil. Standard methods for $\chi^{2}$ tests were used for comparison of their quantitative relation in soils samples from different habitats.

\section{Characteristic of biodiversity}

The methods used and goals of investigations conducted in the "Kościan Plain" differed strongly between the studied taxa or groups. That is, why some data included in this chapter should be regarded rather as the approximate information about "species pool" of organisms occurring there and as a general picture of wildlife taxonomical diversity and richness, but not in the term of detailed, complete datasets on species richness, concise across the taxa in scale of the landscape. Presumably, only the data on vascular plants, butterflies, amphibians and birds represent the groups for which we can evaluate or estimate the number of species for farmland (arable fields, meadows, field margins, small water bodies, drainage ditches) as well as for the whole landscape in broad sense. Other groups can be used for evaluation of biodiversity mostly in respect to farmland ("Turew Mosaic Landscape") or to selected habitats occurring in farmland (for example the fishes for evaluation of small water bodies and water courses importance).

\subsection{Plants}

The total number of the spontaneously occurring vascular plant species, which have been noted until now within the "Kościan Plain" amounts to 848. It comprises just $54 \%$ of the number of species in the Środkowa Wielkopolska Region. There are 773 naturalized species and 75 casual neophytes. Natives are $72 \%$ and all alien species $28 \%$ of the total flora. Among the alien species the most important group are archaeophytes that present $39 \%$ of the total alien species number, whereas naturalized neophytes are $30 \%$ and casual neophytes 31\% [11]. Among the naturalized neophytes there are 4 invasive species (Heracleum sosnowskyi, Echinocystis lobata, Impatiens glandulifera, Reynourtia japonica) from the ministerial list of alien species that especially threat the biodiversity in Poland. As many as 6 of the neophytes that are noted in the Landscape Park (Echinocystis lobata, Elodea canadensis, Impatiens glandulifera, Prunus serotina, Reynourtia japonica, Robinia pseudoacacia) are included in the list of 100 WORST in Europe [42]. The species typical for meadows show the highest share $(22 \%)$ among the sociological groups of plants. The smallest is the group of thicket plants $(5 \%)$. The share of other groups (aquatic, forest, xerothermic grassland, ruderal, segetal) is $11-14 \%$.

Currently, the total landscape flora consists of 828 species due to the extinction of 20 species in the last decades. Nowadays 85 plant species of special care (rare, threatened, declining, protected) occur spontaneously in the "Kościan Plain". Among them, there is one species 
(Ostericum palustre) protected in UE that is in the II Annex to the Habitats Directive, and two species (Botrychium matricariifolium, Ostericum palustre) listed in the "Polish Red Data Book of Plants" [43]. As many as 44 species from this group of special care plants are protected in Poland. Despite their exposure to extinction the other species from this group are not protected. Apart from them 12 valuable vascular plant species had been noted in the past, but they disappeared in the last decades.

The flora of fields that dominate in the landscape, consists of 224 plant species. It is $74 \%$ of the segetal flora of the Wielkopolska Region. Native species are $56 \%$ and alien species $44 \%$ of the total field flora. Archaeophytes that presents $65 \%$ of alien species are the biggest group among them. $21 \%$ are naturalized neophytes and $14 \%$ casual neophytes. In the group of naturalized neophytes there are often noted invasive species as Amaranthus retroflexus, Conyza canadensis, Galinsoga parviflora and Veronica persica and less frequently Anthoxanthum aristatum, Bromus carinatus, Bidens frondosa and Galinsoga ciliata. Among the sociological groups of plants the highest share show segetal species (34\%) and from other sociological groups the biggest are meadow (20\%) and ruderal species groups $(19 \%)$. The share of remaining groups (aquatic, forest, xerothermic grassland, thicket) is 3-8\%. 23 plant species of special care were noted in the fields. Among them there were species threatened in Poland and in the Wielkopolska Region (e.g. Myosurus minimus, Valerianella locusta, Valerianella rimosa, Conium maculatum), vulnerable archaeophytes (e.g. Agrostemma githago, Anthriscus caucalis, Melandrium noctiflorum, Valerianella rimosa) and only one species protected in Poland (Ornithogalum umbellatum) among them [11].

A studies conducted in the mid-1970s showed 131 plant communities in the "Kościan Plain", but actually 122 plant communities were confirmed. Number of aquatic associasions was reduced by 9 only in last four decades.

Forest communities represent less than $15 \%$ of the land cover and most of them are of anthropogenic origin. Pine monoculture stands are the most common forest communities in the area. Natural forest are represented by riparian (elm-oak) and alder stands - which covers narrow areas along water courses. Elm-ash riparian forests are noticed in the vicinity of the alder stands - characterized by lower level of groundwater.

As a result of thousands years of agricultural use of this area, dominating Middle European lowland oak-hornbeam forest habitats (Galio-Carpinetum) have been substituted with arable fields, whereas lowland ash-elm floodplain forest habitats (Ficario-Ulmetum) mostly with intensively cultivated meadows. Predominant deciduous forest habitats have been almost destroyed, and only small forest patches like manor park in Turew remained. As early as in the XIX century this area was among the most intensively used in this part of Europe. Arable fields occupied $65.2 \%$, meadows $-13.5 \%$, pastures $-3.4 \%$, forests $-13.2 \%$. In order to prevent the soil erosion, in 1820 s the then holder D. Chłapowski introduced into fields a network of windbreaking shelterbelts which consisted mainly of Robinia pseudoacacia with some addition of Quercus robur and with hedgerows that consisted of Crataegus monogyna. Consequently, although most of them have been destroyed, the studied area is particularly 
rich in those species and shelterbelts and woodlots with Robinia pseudoacacia are distinctive features of the Park's landscape, distinguishing it from other parts of Poland. This species is not only predominating species or even the only woody species in many shelterbelts, but it was also recognized as the species which was most often found in all woody plant assembles surrounded by arable fields in the investigated area (found in $37 \%$ of all the studied tree lines, belts and clumps growing among crop fields - former Oak-Hornbeam habitat). The other frequently found species were: Quercus robur, Pyrus pyraster and Acer platanoides. In contrast, on meadows the most abundant species were Salix alba and Alnus glutinosa $[17,44]$.

Characteristic feature of "Turew Agricultural Area" is a network of tree or shrub lines or belts, which develop mostly along roads or ditches, and much less frequently constitute border line between adjoining crop fields. Tree and shrub lines constituted $80 \%$ of all woody vegetation clumps in this area [17]. However in most field margins, especially in the area consisted of very small (several hectares) pieces of arable land, there are no perennial (including woody) plant communities. Also thicket communities are very rare in the area. Usually, the anthropogenic habitats gives conditions for grassland communities which enriches biodiversity by creating favorable conditions for many rare plant species in the landscape.

Research of 50 small water reservoirs located in the Kościan Plain showed presence of 40 plant communities [23]. Those communities were often represented by pleustonic plants of Lemnetea class. Most of studied reservoirs with submerged vegetation formed hornwort phytocenoses - Ceratophylletum demersi while very rarely were observed stonewort communities (Characeae). Among the rush vegetation the Phragmitetum australis and Typhetum latifoliae were dominating (poor floristically). Sedge rushes - Magnocaricion were better formed.

In the investigated ecosystems There were noted 180 species of vascular plants, 3 of stoneworts and 1 moss were noted. The analysis of identified plant communities showed that 38 of them are of native origin. Communities of alien species that occurred in small mid-field ponds are formed by Canadian waterweed (Elodea canadensis) and sweet flag (Acorus calamus). The majority of plant communities in the mid-field ponds (29) were distinguished as native communities, which increase their areas as effect of the anthropogenic influence. Phytocoenoses in this category usually inhabit very fertile waters as mid-field ponds. Low diversity of plant species within phytocoenoses show the adverse changes in ecosystems as a result of human activities.

Mid-field ponds are marginal habitats in the agricultural landscape. Regardless of their small area they create conditions in which natural vegetation finds refuge, especially where the intensification of agricultural activities reduces ecological quality of landscape. Therefore, it is useful to enrich the landscape through creation of new and renovation of neglected water ponds. 
One of the objects of investigations in the Turew landscape was the pond (1800 square meters) which was dug in the summer 1995 in natural, periodically flooded area. In this pond aquatic and marsh plant succession was observed in 1995-2005. During the first and second vegetation seasons the stonewort meadows covered 91\% of bottoms area. In 1998 the stonewort domination finished. In that period there were not observed any phytoplankton blooms. After the third year of the pond existence the plants with floating leaves covered large area. The shade the bottom area was the reason of charophytes disappearance. In 2000 the communities of emerged plants dominated in the pond. Since 2003 the patches of hornwort are growing among the other submerged plants. It means the end of the early development stage of the pond. In the pond species rare in Poland and Wielkopolska Region occurred, for example: Chara fragilis, Chara vulgaris, Ceratophyllum submersum and Teucrium scordium.

The most valuable natural plant communities in the "Kościan Plain" are represented by aquatic (peat pits, mid-field ponds, lake and water courses) and meadow phytocenoses. Among the meadow communities the most important for biodiversity are marshy and swamp meadows endangered by drying and intensification of agricultural activities. The sedge (Carex), purple moorgrass (Molinia caerulea) and thistle (Cirsium) meadows were recognized as the most vulnerable to mentioned threats.

It is worth emphasizing that among 122 plant communities noticed in the whole "Kościan Plain", 54 are endangered in Wielkopolska. The most valuable communities are the 23 associations recognized in " $\mathrm{V}$ " category - at risk of extinction (rare or very rare communities or communities consisting of vulnerable species; those are also communities with simplified and poor species composition and with decreasing area of occurrence. Existence of these associations can be prolonged only by preserving actual conditions and reduction of anthropogenic pressure. In addition, 31 associations have been reported in high risk of withdraw - in the "I" category (communities of indeterminate threats because their distribution, dynamic tendency and systematics are weakly recognized). In the investigated area there have been identified 39 that are recognized as indicators of habitat listed in II Annex of the Habitats Directive.

\subsection{Invertebrates}

\subsubsection{General characteristics of invertebrate diversity}

„Turew Mosaic Landscape" favors to preserve high biodiversity level. According to data gathered by numerous authors, there were recorded ca. 3500 species of invertebrates, of that 2600 insects species since 1970s (Table 1), which represent a majority of Central European insect families. The most abundant are the species strictly related to agrocenoses (agrophags) and their natural enemies (predatory and parasitoid species). Some of the species are rare in Poland, many of them (carabid beatles, bumble bees, some butterflies) are protected by law or are listed in Red Lists [45]. Unfortunately, extremely strong differences in sampling efforts between the studied groups and qualitative character of much data do not enable to approximate total species richness. 


\begin{tabular}{|c|c|c|c|c|c|}
\hline Taxon/group & $\begin{array}{l}\text { No of. } \\
\text { species }\end{array}$ & Source & Taxon/group & $\begin{array}{l}\text { No of. } \\
\text { species }\end{array}$ & Source \\
\hline Nematoda & 40 & [46] & Microlepidoptera & $\sim 150$ & Karg (unpubl.) \\
\hline Enchytraeidae & 16 & {$[47]$} & $\begin{array}{l}\text { Coleoptera } \\
\text { Hetero- and }\end{array}$ & $\sim 500$ & Karg (unpubl.) \\
\hline Lumbricidae & 7 & {$[48]$} & Homoptera & $\sim 200$ & Karg (unpubl.) \\
\hline Acarina & 146 & [49] & Hymenoptera & $\sim 600$ & [52] \\
\hline Araneae & 224 & [50] & $\begin{array}{l}\text { - Apoidea } \\
\text { Thysanoptera }\end{array}$ & $\begin{array}{l}260 \\
40\end{array}$ & {$[53,54]$} \\
\hline Water insects & $\sim 190$ & [51] & Orthoptera & $\sim 30$ & Karg (unpubl.) \\
\hline - Odonata & 36 & & Dermaptera & $>5$ & Karg (unpubl.) \\
\hline - Heteroptera & 41 & & Blattoptera & $>2$ & Karg (unpubl.) \\
\hline - Ephemeroptera & 10 & & Diptera & $\sim 300$ & Karg (unpubl.) \\
\hline - Coleoptera & $>90$ & & Others & $\sim 50$ & Karg (unpubl.) \\
\hline Macrolepidoptera & $\sim 500$ & Karg (unpubl.) & & & \\
\hline - bu & 51 & yk (unpubl.) & & & \\
\hline
\end{tabular}

Table 1. Number of species in invertebrate taxa.

\subsubsection{Insects}

The studies that have been carried out for above 40 years on above-ground insects of agrocenoses and small wooded patches, tree belts and lines, enable evaluation of their status and changes they are undergoing. The results of these investigations indisputably show the crucial role of semi-natural habitats in preserving insect diversity in an agricultural landscape. Biomass, abundance and diversity of above-ground insect communities in small wooded patches and in ecotone zone are on average significantly bigger than in open arable land. What is more, the abundance of predatory and parasitoid species, which play important biocenotic function, is in small wooded patches markedly higher, too.

Small wooded patches constitute refuge area as many species of insects can find there a favorable condition for wintering. The differences in density and biomass of insects between wooded area and crop fields are significant. In the first habitat and in ecotone zone $(0.5 \mathrm{~m}$ wide) the values were several tens higher than in adjacent crop fields. More detailed information on distribution and abundance pattern of insects in relation to habitat and landscape structure are included in Chapter 5.2.

As many as 51 butterfly species were recorded in the "Kościan Plain". Most of them were found in two ecotones - between wooded area and crop fields (27 species) and between wooded area and meadows (41 species), where the butterfly abundance was 4-5-fold higher than in the previous ecotone. There were observed a few species listed in Red List: Lycaena dispar, Colias myrmidone and two other species worth to conserve regionally: Heteropterus morpheus and Polyommatus amandus. Lycaena dispar, hydrofilous species, inhabited meadows with drainage ditches, where larvae of the species could easily find their food - Rumex hydrolapatum Huds. Additionally, some observations of second generation of the species evidence for a favorable conditions, which characterize some habitats of the studied 
landscape. The population density of the species in wooded patches surrounded by crop fields amounted to $0.1 \mathrm{ind} . / \mathrm{km}$ and in ecotones at wooded areas and meadows $-0.8 \mathrm{ind} . / \mathrm{km}$. The presence of dense network of shelterbelts, tree alleys, etc., favors relatively easy dispersion of the rare species from the breeding habitat across the landscape.

\subsubsection{Spiders}

In the "Kościan Plain" as many as 224 spider species (27\% of Polish spider fauna) were observed and 17 species are listed in "The Red list of threatened and endangered animals" most species with VU (vulnerable) status, one with EN (endangered) status. Of that, 204 species were found in the "Turew Mosaic Landscape" and 19 other species - exclusively in forest island constituted by a village park in Turew were noted $[55,56]$.

In total, 21 spider families were noted, what constitutes $56 \%$ of all spiders families of Poland. The first three spider families, which are most numerous in species, were in the same sequence as in the whole Polish spider fauna. Linyphiidae was the most species-rich spider family and it was represented by 63 species ( $32 \%$ of the pool of species occurring in crop fields and shelterbelts), and the next ones were: Theridiidae -19 species (30\%) and Lycosidae - 18 species (28\%), respectively. The other frequently represented families were: Gnaphosidae -17 species, Salticidae -14, Araneidae -13, Thomisidae and Philodromidae - 9, Tetragnathidae -7 , Clubionidae and Dictynidae -6 species. The rest of families was represented by 1-4 spider species.

\subsection{Fish}

Zbęchy Lake, the biggest basin in the "Kościan Plain" is inhabited by 11 species (bream Abramis brama, roach Rutilus rutilus, silvery crucian carp Carassius gibelio, common crucian carp Carassius carassius, tench Tinca tinca, carp Cyprinus carpio, ide Leuciscus idus, pike Esox lucius, perch Perca fluviatilis, pikeperch Sander lucioperca, eel Anguilla anguilla) from four families: Cyprinidae, Anguillidae, Percidae and Esocidae (by Polish Angling Association, the Fishing Company in Osieczna). Fish in the „Wyskoć Canal” are represented by six families (Cyprinidae, Anguillidae, Percidae, Esocidae, Gasterosteidae, Gadidae and Cobitidae) and 14 species (roach, rudd Scardinus erythrophtalmus, bream, gudgeon Gobio gobio, common crucian carp, silvery crucian carp, tench, three-spined stickleback Gasterosteus aculeatus, bleak Alburnus alburnus, perch, pike, eel, burbot Lota lota. Particularly valuable species, listed in Annex II of the Habitats Directive (Council Directive 92/43/EEC), is mud loach (Misgurnus fossilis).

\subsection{Amphibians}

The "Kościan Plain" is inhabited by 12 amphibian species. It is $67 \%$ of all amphibian species living in Poland and $86 \%$ of lowland amphibian species. The two species not recorded here, are rare (natterjack Bufo calamita) or very rare (agile frog Rana dalmatina) in Poland. The most common amphibians in the agricultural landscape belong also to the most common in Poland: water frogs (edible frog Pelophylax esculentus and pool frog P. lessonae) - inhabited 
$94 \%$ of all water bodies, brown frogs (common frog Rana temporaria and moor frog R. arvalis) - found in $89 \%$ of reservoirs. To the rarest species, inhabited less than $10 \%$ reservoirs, belong marsh frog Pelophylax ridibundus and the European tree frog Hyla arborea [57, 28, 29]. One species (crested newt Triturus cristatus) is included in the Polish Red Book of Vertebrates (with the statuts NT - near threatened) and two other ones (crested newt and fire-bellied toad Bombina bombina) in the Polish Red List, with the status NT and DD (data deficient), respectively. The same two species are included in Appendix II of EU Habitat Directive. Crested newt and fire-bellied toad are not common in the study area - they were found in $20-30 \%$ of all investigated water reservoirs.

All types of water bodies and landscapes within the "Kościan Plain" were inhabited by similar number of species (11-12), but they differed in frequency and abundance of species. The highest number of species was noted in water bodies located in forests (mean 6.6 per reservoir) and in ponds surrounded by cultivated fields (6.2) and the lowest one - in reservoirs in meadow complexes (4.8). The species that occurred mostly in forest are: pool frog (70 \% sites), moor frog $(65 \%)$ and crested newt (35\%). In the ponds in cultivated fields bred mainly (60-70\% of sites) common spadefoot (Pelobates fuscus) and common frog. One species - green toad (Bufo viridis) - was found mostly (40\%) in village ponds. The most abundant amphibian populations (> 500 individuals) were observed in forest $(17 \%$ of all sites) and in meadow ( $8 \%)$ reservoirs.

\subsection{Birds}

\subsubsection{Regional species pool}

Total number of breeding species recorded in the "Kościan Plain" (in all habitats) amounted to ca. 120 [58]. Complete study on breeding bird community in the "Turew Mosaic Landscape" was carried out in 1991-1994 near Turew on the area of 1380ha (crop fields - 80 $\%$, grasslands - $12 \%$, small wooded patches and lines $-5 \%$, roads $-2 \%$, water bodies and courses $-1 \%$ ) [59]. As many as 76 species were found to nest (with the population density of 140 pairs/100 ha) in that mosaic landscape. Small wooded patches were the most important as they covered only $5 \%$ of studied area, while constituted breeding habitat for as much as $88 \%$ of species $(\mathrm{N}=67)$ species and $54 \%$ of all breeding pairs. Although the studied community consisted mostly of species known as common and abundant in Poland, population density of several species which are considered to be threatened and/or rare in Europe was relatively high. It concerns e.g. ortolan bunting (Emberiza hortulana), corn bunting (Emberiza calandra) and red-backed shrike (Lanius collurio). The community included also some species from Polish Red List (DD - quail Coturnix coturnix and European turtle dove Streptopelia turtur) and from Appendix 1 of EU Bird Directive (white stork Ciconia ciconia, marsh harrier Circus aeruginosus, black woodpecker Dryocopus martius, barred warbler Sylvia nisoria, red-backed shrike, ortolan bunting, tawny pipit Anthus campestris).

\subsubsection{Variability in landscape scale}

Species number in the "Turew Mosaic Landscape" differed strongly between its fragments (with the area of 35-55ha). The minimal number of species (4) was observed in a plot 
without wooded areas, with distinctive predominance of crop fields (98.8\%), the maximal one (33) was recorded in the mosaic-like area, rich in a variety of tree lines and patches. The population density was much less variable and ranged from 13 to 33 pairs/10 ha [59].

\subsubsection{Variability of bird communities in small wooded patches and lines.}

The analyses presented here were done for the data on 74 various tree lines (length $<3 \mathrm{~km}$ ) and patches (area $<10 \mathrm{ha}$ ) studied in 1991-1994 [32], and for 68 patches $(<4$ ha) studied in 2005-2007 [60]. In 53 tree lines as many as 54 breeding species were observed. However, the use of species richness estimators for that dataset suggests that total number of species could be even higher - ca. 60 (ca. $1 / 4$ of breeding avifauna in Poland). The species number per single

plot (i.e. tree line) ranged between 1 and 28, with arithmetic mean amounting to $12 \pm 6.3$ (SD). Total density amounted $1-134$ pairs $/ \mathrm{km}$, on average $26 \pm 22$ pairs $/ \mathrm{km}$. In small wooded patches as many as 56 species (3-23 per patch, on average 12.1 \pm 5.4 ) were observed. According the Jack-Knife2 species richness estimator one may expect more than 80 species (Figure 5) in all types of wooded patches, tree lines etc. Among dominating species ( $>5 \%$ of community) were finch (Fringilla coelebs), blackcap (Sylvia atricapilla), yellowhammer (Emberiza citrinella), great tit (Parus major), nightingale (Luscinia megarhynchos), blackbird (Turdus merula) and icterine warbler (Hippolais icterina). Total population of breeding birds amounted to 125 pairs/10ha.

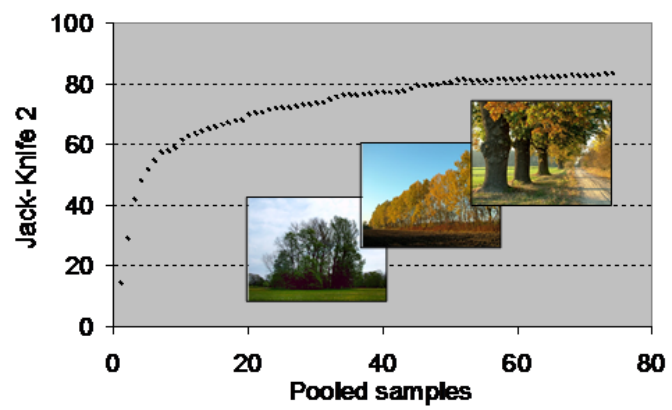

Figure 5. Species richness in wooded patches. Photo K. Kujawa.

\subsection{Mammals}

A list of big-sized mammal species in the "Kościan Plain" is based on field observations in the years 1998-2012 and references. Rodents were diagnosed on the basis of research carried in recent years by the CMR method, while the presence of other species was based on direct observation. Most of the recorded species are commonly encountered in this area commonly. There are no species for which the "Kościan Plain" would provide a key role in preserving their populations. However, the presence of protected species indicates the attractiveness of the area for those groups of animals. As many as 32 species (with the 
exception of bats), representing 14 families, were recorded in the area: mole Talpa europaea (partially protected), common shrew Sorex araneus (strictly protected), Eurasian water shrew Neomys fodiens (strictly protected), brown hare Lepus capensis, red squirrel Sciurus vulgaris (strictly protected), beaver Castor fiber (partially protected), water vole Arvicola terrestris (partially protected), red vole Myodes glareolus, common vole Microtus arvalis, field vole Microtus agrestis, house mouse Mus musculus, field mouse Apodemus agrarius, yellow-necked mouse Apodemus flavicollis, wood mouse Apodemus sylvaticus (partially protected), harvest mouse Micromys minutus, brown rat Rattus norvegicus, red fox Vulpes vulpes, raccoon dog Nyctereutes procyonoides, Eurasian lynx Lynx lynx (seen once), badger Meles meles, European otter Lutra Lutra (partially protected), pine marten Martes martes, beech marten Martes foina, least weasel Mustela nivalis, American mink Neovison vison, common raccoon Procyon lotor, wild boar Sus strofa, roe deer Capreolus capreolus, red deer Cervus elaphus, fallow deer Dama dama, Eurasian elk Alces alces (seen once), mountain sheep Ovis ammon [61, 34]. Two species - beaver and European otter - are listed in the annexes of the Habitats Directive. Traces of beaver were found mainly along of watercourses, e.g. Wyskoć Canal, but in melioration ditches, too. Fauna of bats requires additional research, but it is estimated that there are approximately 12 species of bats.

Mid-field shelterbelts are an important element of agricultural landscape for small mammals. Shelterbelts are mid-field refugees, food source and ecological corridors. They also join scattered elements of environment in mosaic landscape. Small mammals in the shelterbelts were studied e.g. by $[62,63]$. Rodents can migrate for the longest distances along shelterbelts. In the shelterbelts, many species find the conditions for the reproduction and rearing, the overwintering or survival in the case of unfavorable weather conditions. Also wooded areas can be a food source for many species of mammals, often in the winter decisive for survival, or a supplemental food source. Seven species of small rodents $(47 \%$ of Polish fauna) were recorded in the studied shelterbelts. In the old shelterbelt, yellow-necked mouse Apodemus flavicollis dominated markedly (55\% of captured animals). Also numerous individuals of field mouse Apodemus agrarius (18\%) and common vole Microtus arvalis (19\%) were found. Additionally, individuals of wood mouse Apodemus sylvaticus, house mouse Mus musculus, harvest mouse Micromys minutus and bank vole Myodes glareolus were captured. In the young shelterbelts, small mammals were much more abundant but species structure was different than in the old ones. Field mouse dominated here (45\%). Common vole was also numerous (32\%). Other species (yellow-necked mouse, wood mouse, house mouse, bank vole) were much less frequent. According to classification by [64, 65], in which small mammals can be divided into "forest" species (yellow-necked mouse, bank vole), "field" species (house mouse, harvest mouse, common vole) and "intermediate" species (wood mouse, field mouse), our study indicates, that the old shelterbelt is an environment similar to the forest. In the young one, domination of "field" and "intermediate" species was observed. Small mammals were also studied in manorial park in Turew. Species typical for forest environment strongly dominated there (bank vole 54\%, yellow-necked mouse 15\%). Field mouse was also observed here (30\%). Common vole was captured here only occasionally. 


\subsection{Fungi}

\subsubsection{Macrofungi}

At first, it is worth to note that an agricultural landscape, till now, has been only rarely considered as the area, on which preservation of national species pool strongly depends. Only few studies on species diversity of Macromycetes (species, which can be observed with unarmed eye) have been carried out in agroecosystems and exceptionally in scale of landscape. The results of a study conducted since 1997 in the "Kościan Plain" indicate that mosaic-like agricultural landscape, rich in non-farmed habitats such as village parks, small wooded patches, menaged tree stands, is inhabited by a variety of fungal species, including rare and protected ones. In 1997-2011 as many as 687 species were found (Kujawa A., unpubl.), in that 99 from Ascomycota and 588 from Basidiomycota. According to substrate on which fungi grow, most frequent (55\% of all species) were terricolous species (Figure 6A). Apart main type of substrates (soil, wood and litter), the fungi were found also on dung, dead fruitbodies, wood charcoal) and some others were parasites of herbs and insects. With respect to trophy, most species belongs to saprotrohic group (Figure 6B).

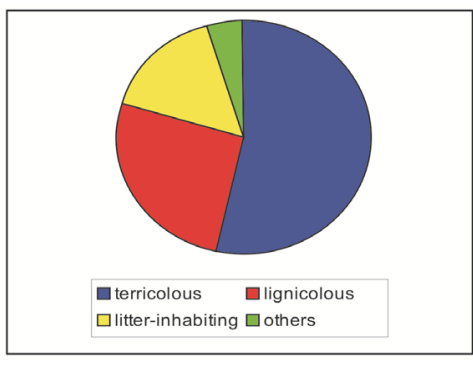

(a)

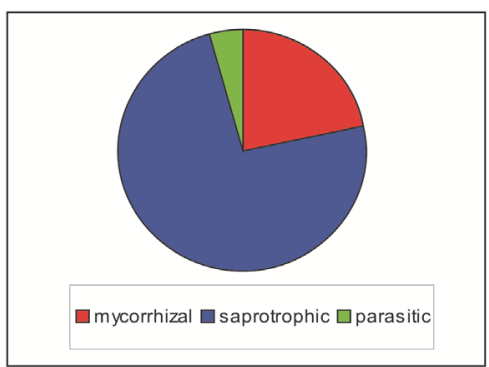

(b)

Figure 6. Share of species according to: a) substrate inhabited; b) their trophy.

Most of the studied elements of the „Kościan Plain” play a role of substitute habitats for some rare species and species protected by law. It is worth underlining, that $26 \%$ of species observed in the "Kościan Plain" study area belong to the group of special concern species, i.e. these species which follow at least one of the below listed criteria:

a. Species protected by law [66] - 17 species, e.g. Sarcocypha austriaca, Grifola frondosa, Sparassis crispa, Verpa conica, Fistulina hepatica, Geastrum striatum, G. berkeleyi, G. coronatum.

b. Threatened species, listed in "Red list of the macrofungi in Poland" [67] - 98 species, e.g. Coprinus bisporus, Crepidotus luteolus, Entoloma rhodocylix, Hygrocybe insipida, Inocybe calospora, Lepiota brunneoincarnata.

c. Threatened species, listed in "European red list of the macrofungi" (Ing 1993) - 18 species, e.g. Cordyceps capitata, Entoloma excentricum, Lepiota fuscovinacea, Mycenastrum corium, Perenniporia fraxinea 
d. Rare species, not protected by law and included in red lists, but observed in Poland only in 1-2 sites, in that the species found exclusively in the "Kościan Plain", according to checklist of Polish larger Basidiomycetes [68], checklist of Ascomycetes in Poland [69, 70] - 79 species, e.g. Conocybe fuscimarginata, Entolona araneosum f. fulvostrigosum, E. cephalotrichum, E. incarnatofuscescens, Marasmius anomalus, Peziza ampliata,Xylaria oxyacanthae .

e. Species found first time in Poland (in that, recorded exclusively in the "Kościan Plain") - 25 species, e.g. Desmazierella Desmazierella piceicola, Entoloma parasiticum, Gammundia striatula,Hohenbuehelia cyphelliformis, Melanomphalia nigrescens, Pustularia patavina.

\subsubsection{Microfungi}

The total number of the species of entomopathogenic fungi collected in the "Kościan Plain" amounted to 88. As many as 60 species were found in the "Turew Mosaic Landscape". The poorest resources of that group of organisms were regularly noted in both kinds of annual crops (cereal and row crops), where only 20-25 species occurred and the majority of them was connected with the roadside, balk or ruderal vegetation. However, even in such inhospitable conditions occur not rare epizootics in aphid colonies or adult anthomyid flies - mostly of the genus Hylemya - caused by Zoophthora, Pandora and Entomophthora species on big areas of cereals and rape seeds [71].

The main taxonomical units grouping the majority of obtained arthropod pathogenic species of fungi were the orders of Entomophthorales and Hypocreales. The greatest significance of the first order for the restriction of agrophagous and forest pest arthropods results from their spontaneous dispersal in dense host populations, ending often by almost total their mortality. Only few of representatives of the second order are able to form the perfect (ascomycetous) fructification form, but they produce as a rule abundant and strongly differentiated vegetative (conidial) sporulation forms (called anamorphs), allowing their overall dispersion and permanent restriction of arthropods. Their most common genera, as Beauveria, Isaria, Lecanicillium, Metarhizium, Simplicillium are polyphagous, non-selective with respect to a host species, permanently sustaining in soil conditions [72] and in "aeroplankton". Moreover, many of their strains have been applied as "active agents" in commercial biopesticides.

As many as eight entomopothogenic fungal species were found in soil of agrocenoses and semi-natural habitats [72]. Generally, three species of fungi: B. bassiana, M. anisopliae and I. fumosorosea, dominate in Polish soils. The dominance of particular species depended on habitat. In the soils from arable fields $M$. anisopliae dominated, with I. fumosorosea and $B$. bassiana as subdominants. M. anisopliae, B. bassiana and I. fumosorosea predominated in the soils from meadows and pastures, whereas B. bassiana in samples from forest soil and litter. It was found that infective potential and density of CFU of entomopathogenic fungi were significantly higher in soils from old or medium age shelterbelts than in adjacent large-area arable fields. Moreover, the soils from shelterbelts were characterized by more abundant fungal species composition ( 6 vs. 3 species respectively), being specific refuges for resources, 
diversity and persistence of entomopathogenic fungi in the agricultural landscape. Particularly valuable in this respect seem to be scrubby shelterbelts of rich species composition.

\section{Impact of landscape structure and land-use}

\subsection{Plants}

Floristic diversity of the whole agricultural landscape depends on landscape complexity. Results of the study on relationships between the floristic diversity of farmland and the diversity of its structural elements have shown a strong relationship between them [11]. The flora value increases with the number of spatial elements in the landscape (Figure 7).

Results of the study have proved that in a homogeneous landscape, composed of only arable fields and linear mid-field elements, the species number is half as high as in a landscape with numerous habitat islands. In fields, 224 plant species were noted. It was only $27 \%$ of the total landscape flora. The number of weed species in each field depended on method of cultivation and type and size of crop. The greatest species richness is characterized by small fields of farmers applying the extensive methods of cultivation.

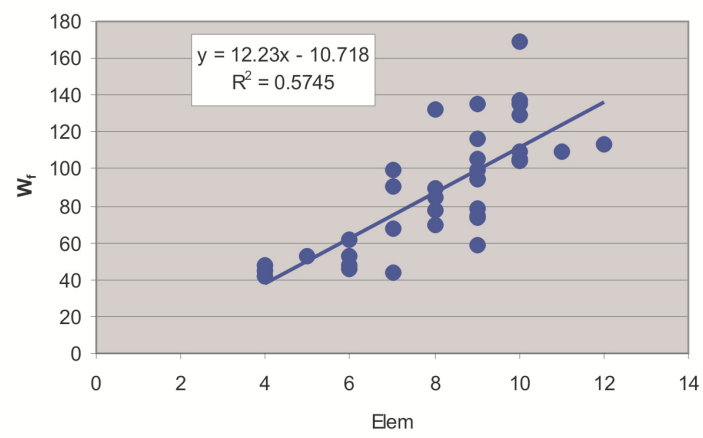

Figure 7. Relationship between the floristic value $\left({ }^{*} \mathrm{Wf}\right)$ and the number of landscape elements (Elem) * $\mathrm{Wf}$ - the floristic value is the sum of the rarity coefficients of the naturalized plant species that are noted on the plots $\left(1 \mathrm{~km}^{2}\right.$ each)

The studied landscape consists of various spatial elements with various land use. Evaluation of these elements allowed to point out those with the highest conservation value, which increase floristic diversity in agricultural landscape most significantly. Among them there are: water reservoirs and ditches, meadows, forests and manor parks. Nearly all the elements of the agricultural landscape, both patch-like and linear, are refuges for threatened and other environmentally valuable species.

The research on the flora carried on in the previous century was summarized by [6]. The study indicated that water reservoirs and meadows located in agricultural landscape are the habitats that provide refuge site for the greatest number of threatened species. 
Lake differs from other landscape elements in plant cover, which is the most natural, and in numerous occurrences of species that are especially vulnerable to human impact. Rare species for the flora of Poland and Wielkopolska Region and taxa included in red lists of plants are noted more often in the water column and in the belt of rush of the lake than in other water reservoirs (e. g. Hippuris vulgaris, Lathyrus palustris, Calamagrostis stricta, Carex disticha, Cladium mariscus, Dactylorhiza majalis, Juncus ranarius, Lotus tenuis, Nuphar lutea, Schoenoplectus tabernaemontani, Tetragonolobus maritimus, Teucrium scordium, Valeriana dioica). They represent $32 \%$ of the total flora of the lake. The share of the native species group is very high (nowadays it is 95\%) [11].

Species that are protected by law are the most numerous in peat pits. The flora of those biotopes is most similar to the flora of lakes in respect to natural value. Among threatened species, the following are worth mentioning are: Achillea ptarmica, Calamagrostis stricta, Carex disticha, Cladium mariscus, Dactylorhiza majalis, D. incarnata, D. maculata, Hydrocotyle vulgaris, Lathyrus palustris, Menyanthes trifoliata, Nuphar lutea, Nymphaea alba, Pedicularis palustris, Schoenoplectus tabernaemontani, Teucrium scordium, Utricularia vulgaris, Viola palustris. About $27 \%$ of peat pits total flora are valuable species.

High naturalness has distinguished also the flora of linear elements of landscape that are included in meliorative systems. Those are canals and ditches lying among meadows. Native species are $97 \%$ of this flora. Species typical for aquatic ecosystems and meadows have dominated in the sociological plant groups. The only records of Batrachium fluitans, Sagittaria sagittifolia and Sparganium emersum were found in canals and the only locality of Alisma lanceolatum in a ditch.

Ponds and midfield ditches are often the only aquatic ecosystems within rural areas. Thus the flora of them is especially valuable for biodiversity despite of their anthropogenic origin. This concerns particularly areas with big fields and intensive management. Those biotopes enrich poor agricultural landscape with a group of native species, also of the ones which are typical for natural ecosystems. Those are most of all aquatic, forest and ticket taxa. The flora of midfield ditches consists mainly of common species, but sometimes species from a vulnerable group can be observed. Those are e. g. protected by law Batrachium trichophyllum, Centaurium pulchellum, Hedera helix or sufficiently rare in Wielkopolska Region Carex cuprina and Sagina nodosa. Among all tree and shrub lines in the studied area, the dendroflora of the ones that were situated along ditches was the most natural and the share of native species was the highest [17].

Ponds are refuges for many aquatic and marsh species in agricultural landscape and therefore they are very important in maintenance of biodiversity. The only records of such species as Potamogeton gramineus and Potamogeton trichoides were observed in ponds. The flora of ponds is characterized by a higher share of alien species than the other aquatic biotopes. It is highest in case of naturalized neophytes [11].

The intensity of agriculture of the studied area rose during the last 30 years what resulted in the increase of the significance of agricultural nonpoint pollution leading to the eutrophication of ecosystems. 
Thus changes in the flora of aquatic and marsh ecosystems (lake, peat pits, Wyskoć Canal) under increasing human impact were analyzed [20]. This was achieved by comparing the present flora of these habitats with their flora reported in the late 1970s. Vascular plant species richness during the last 30 years increased by 40, as 15 species disappeared and 55 new appeared. However, 6 moss and 4 stonewort species disappeared and only 3 new moss species were found (Table 2). The Wilcoxon test, taking into account changes in the dynamics of individual species, indicated statistical significant differences between the studied periods $(\mathrm{Z}=2.531, \mathrm{P}=0.011)$. In the case of apophytes they were significant both in their number in both periods (sign test $Z=6.019, P<0.001$ ) and their dynamics (Wilcoxon test $Z=5.453$, $\mathrm{P}<0.001$ ). Also the redundancy analysis (RDA) revealed significant differences in flora between the two study periods as the variables 'Present' and 'Past' were highly significant (F $=7.7 ; \mathrm{P}<0.0001)$. In the case of apophytes they were significant both in their number in both periods (sign test $Z=6.019, P<0.001$ ) and their dynamics (Wilcoxon test $Z=5.453, P<0.001$ ).

\begin{tabular}{lcc}
\hline & \multicolumn{2}{c}{ The number of plant species } \\
Item & $1976-1980$ & 2006-2007 \\
\hline Total flora & 152 & 185 \\
Vascular plants & 129 & 169 \\
Stoneworts & 9 & 5 \\
Mosses & 14 & 11 \\
Endangered from the red lists & 25 & 18 \\
New species of vascular plants & - & 55 \\
Disappeared vascular plants & - & 15 \\
Disappeared stoneworts & - & 4 \\
Disappeared mosses & - & 6 \\
New mosses & - & 3 \\
Nonsynanthropic native species & 87 & 87 \\
Apophytes (synanthropic native species) & 40 & 73 \\
Archaeophytes & 0 & 2 \\
Naturalized neophytes & 2 & 6 \\
Casual neophytes & 0 & 1 \\
Share of valuable species in the total flora (\%) & 51 & 37 \\
\hline
\end{tabular}

Table 2. Transformations of the aquatic and marsh flora

Nearly all undetected species were rare in the Wielkopolska region. They are e.g. Batrachium trichophyllum, Carex diandra, Carex rostrata, Gentiana pneumonanthe, Hippuris vulgaris, Pedicularis palustris, Potamogeton friesii. However, complete disappearance of the water soldier (Stratiotes aloides) which was a very common species in peat pits in 1976-1980 was very spectacular. It is also interesting that hornwort (Ceratophyllum submersum) which was very rare in the Wielkopolska Region between 1976 and 1980 and only one record of it was known in the Kościan Plain (in a mid-field pond), widespread in the last 30 years. At present, patches of this species are often found in various types of water body. 
Among the new species, the most common were apophytes (i.e. the synanthropic native species capable of occupying the habitats transformed by human activity). Among the species that disappeared from the flora, $84 \%$ are nonsynanthropic spontaneophytes (i.e. the nonsynanthropic native species). An increase in the percentage share of apophytes (from $31 \%$ up to $43.2 \%$ ) and of alien species (from $1.6 \%$ up to $5.3 \%$ ) in the flora caused a decrease in the naturalness index (the percentage share of nonsynanthropic spontaneophytes in the flora) of aquatic and marsh flora from $67.4 \%$ to $51.5 \%$.

In the group of new species there are 2 species of invasive neophytes. They are: Bidens frondosa and Echinocystis lobata. Bidens frondosa widespread already in the Kościan Plain landscape and outcompeted the native Bidens species, which completely disappeared from the flora of studied ecosystems. Echinocystis lobata has appeared in the natural vegetation patches in the last decade and its invasion in the next years is very probable.

In the group of species that disappeared there are only those characteristic for aquatic and meadow communities. New components of the flora are species from various sociological groups. Segetal and ruderal species, which mostly decrease the naturalness index, are $14 \%$ of the new species group.

14 moss species were found in aquatic and marsh ecosystems in 1976 - 1980. Their number decreased to 11 (Table 1). Two species protected by law disappeared (Drepanocladus sendtneri and Leptodictyum humile) and a new one appeared (Amblystegium radicale). Three calciphilous species vanished from the moss flora (Drepanocladus sendtneri, Campylium polygamum, Campylium stellatum). Fontinalis antipyretica, which in 1976-1980 was a very common component of the aquatic flora in the lake, currently belongs to the group of potentially endangered species. The frequency of occurrence of this species decreased by over $90 \%$.

The flora of stoneworts (Characeae) decreased in number by 4 species (Chara aculeolata, $C$. contraria, C. polyacantha, C. vulgaris). All of them were included in the red list of stoneworts in Poland. Chara polyacantha was an especially valuable species because it is very rare in Polish flora and is protected by law.

A very significant decrease in the frequency of Chara fragilis and Nitellopsis obtusa (by 75\% and $65 \%$, respectively) was observed in the time interval of the investigations. These species, especially Nitellopsis obtusa, belonged to the most important components of submerged plant associations in the lake in 1976-1980.

Phytosociological studies on the vegetation of aquatic ecosystems were also carried out (Tab. 3). The total number of plant communities that were distinguished was 77. Half of them are mentioned in the list of threatened plant communities in Wielkopolska Region. The most valuable is the vegetation of peat pits - the highest number of species threatened, rare and vulnerable to human impact communities occurs in those biotopes. The highest phytocoenotical diversity characterized ponds and ditches lying among meadows. The smallest is the diversity of plant communities in midfield ditches.

Plant communities of the lake, peat pits and Wyskoć Canal were studied from the half of 1970, so it was possible to follow the transformation of them during the thirty-year period 


$\begin{array}{lccc}\text { Kind of ecosystem } & \text { Number } & \mathrm{R} & \mathrm{V} \\ \text { Lake } & 22 & 4 & 12 \\ \text { peat pits } & 36 & 8 & 23 \\ \text { Canals } & 25 & 2 & 8 \\ \text { ditches among meadows } & 44 & 7 & 18 \\ \text { Ponds } & 48 & 7 & 19 \\ \text { ditches among fields } & 20 & 2 & 4 \\ \text { all ecosystems } & 77 & 15 & 38\end{array}$

Table 3. Phytocoenotic diversity of aquatic ecosystems (Explanations: $\mathrm{R}$ - rare, $\mathrm{V}$ - vulnerable)

(1976-2006). Nine communities of aquatic plants and one of bulrush community have perished in all the studied ecosystems. Only one of them is not endangered in the Wielkopolska Region. Almost all are very rarely met in the Kościan Plain landscape. During the thirty years the number of plant associations (mainly components of the rush belt), as well as the number of the species that constituted them, simultaneously increased.

In Lake Zbęchy 5 associations of submerged plants disappeared [18].The maximal depth of plant occurrence decreased from $3.6 \mathrm{~m}$ in 1976 to $2 \mathrm{~m}$ at present. This caused a reduction of total phytolittoral area by 50 percent. The area overgrown by submerged macrophytes decreased from 13 to 2 ha. Valuable plant associations like Nitellopsidetum obtusae, Myriophylletum spicati, Najadetum marinae, Potametum lucentis, Cladietum marisci, and Scirpetum maritimi, considered as endangered in the Wielkopolska Region, disappeared in the lake, or the area of their occurrence decreased.

At the same time cyanobacteria blooms which were not observed in the 1970s appeared. The appearance of blooms at present in the lake can be linked to the disappearance of submerged macrophytes, especially the extinction of Nitellopsidetum obtusae that dominated this area thirty years ago.

The most important change in Wyskoć Canal was the complete disappearance of patches of Sagittario-Sparganietum emersi association, which dominated in 1970s [19]. Three aquatic plants associations (Charetum aculeolatae, Myriophylletum verticillati, Stratiotetum aloidis), which nowadays are included in the list of endangered communities, disappeared from the peat pits [21].

The study on the flora of meadows has shown that they are very valuable for biodiversity of the whole agricultural landscape. They are distinguished by a high total number of species that is $45 \%$ of the total landscape flora, the highest native species diversity and the highest number of vulnerable species [6, 11]. However, during the last 30 years serious changes of the meadow flora were observed, particularly regarding marsh meadows, which are habitat of many endangered and protected plants. As a result of the changes, vegetation of meadows becomes homogeneous and the same everywhere. Rare plant species disappear and common grasses grow in their place. Alchemilla monticola, Crepis praemorsa, Eleocharis quinqueflora, Eriophorum latifolium, Euphrasia rostkoviana, Pulicaria vulgaris, Viola stagnina were 
among plant species that vanished during the last decades. Sites of many valuable species such as Carex davalliana, Dactylorhiza incarnata, D. majalis, D. maculata, Dianthus superbus, Gentiana pneumonanthe, Parnassia palustris, Pedicularis palustris, Polygala amarella, Tetragonolobus maritimus and Triglochin maritimum are threatened and they are constantly decreasing. As yet, Ostericum palustre occurs numerously and in many places, but it is also endangered because of a decrease of wet meadows area and intensification of meadow management.

Forests and manor parks are very important for biodiversity of agricultural landscape despite occupation of small surface. Their species richness is almost the same as in meadows (species noted in all the kinds of forests were $40 \%$ of the whole landscape flora). The number of vulnerable species is bigger than in forests only in meadows. The most interesting of those species is daisy leaf grape fern (Botrychium matricariifolium). It was found in habitats under big human pressure - economically used monocultures of oak and ash, where some typical practices linked with cultivation of trees were regularly carried out [73]. The species is very rare in flora of Poland and strictly protected. Apart from this species, in the group of vulnerable plants of forests and parks also such species as Calamagrostis stricta, Campanula latifolia, Cucubalis baccifer, Gagea arvensis, G. minima, Leucoium vernum, Listera ovata, Lycopodium annotinum, Ophioglossum vulgatum, Platanthera bifolia, Teucrium scordium etc. were noted.

Majority of forests on the explored area are of anthropogenic origin. Separate studies, carried out on the flora of 15 planted shelterbelts lying among fields, showed that 100 species of vascular plants occurred there - they were 30 tree and shrub and 70 herb species. $83 \%$ of all the species were native and $17 \%$ were alien species. It was more than in natural alder forest, where the share of alien species was only of $5 \%$, but equal or less than in all the forests in the landscape, where the mean share of this species group was of $18 \%$ [11]. In the group of alien species there were archaeophytes ( $8 \%$ of all species noted in shelterbelts) and naturalized neophytes (9\%). The share of alien species was bigger in the tree and shrub layer $(27 \%)$ than in the herb layer $(13 \%)$. The group of alien species in the herb layer in majority constituted from archaeophytes (10\% of all species), while among tree and shrub alien species naturalized neophytes dominated (24\%). Three of the naturalized alien species common robinia (Robinia pseudoaccacia), black cherry (Padus serotina) and box elder (Acer negundo) - are mentioned as invasive species that endanger the biodiversity in Poland [42]. Common robinia and black cherry are included in the list of 100 worst alien species in Europe (DAISIE - 100 of the worst http://www.europe-aliens.org/ speciesTheWorst.do). The most recently found expansive and potentially dangerous alien woody taxon was Amelanchier sp. [17].

Out of 86 segetal weed species which occurred in the flora of all the landscape 76 species were observed on arable fields and only 9 in shelterbelts. In addition, only 5 of those noted in shelterbelts were met in the flora of fields. The other 4 species were very rare in the flora of the Turew landscape e.g. sharp-leaved fluellen (Kickxia elatine) which is a vulnerable archaeophyte in Poland [74] and is also published on the red list of plants of the Wielkopolska Region [75]. Shelterbelts were the only localities of this and several other 
species in the studied area. Therefore these anthropogenic biotopes may also constitute refuges of rare plant species. According to [76] segetal weeds have appeared in masses only in young shelterbelts. The vegetation of older and stabilized shelterbelts is peculiar and they are not a place from which weeds widespread on the fields.

As a result of investigation (2001-2003) of woody species in tree lines, avenues, shelterbelts, hedgerows and woodlands surrounded by arable fields or intensively used meadows in the central part of the Kościan Plain in 467 mature objects 86 species have been found [17]. The most often noted species was Robinia pseudoacacia. The other considerably often noticed species were: Quercus robur, Pyrus pyraster and Acer platanoides. In contrast, on meadows Salix alba and Alnus glutinosa most often occurred. The number of wooded species in each object varied from 1 to 22 .

Generally, tree lines among arable fields were richer than the ones on meadows. On the other hand, the alien species were more common there and had higher share. Total number of alien and cultivated woody species in tree and shrub lines surrounded by arable fields was similar to the number of native species, whereas in those on meadows number of native species was higher. As a matter of fact, around arable fields there was no wooden vegetation patch (wood) which tree layer consisted of native species only. On the contrary, on meadows there were $29 \%$ such small woods.

\subsubsection{Factors determining plant diversity}

The key factor determining richness of plant species and diversity is the landscape structure. In the agricultural landscape all the elements that are different from arable fields, both patch-like and linear, are refuges for environmentally valuable species. Thus, the most serious threat to biodiversity is the loss of appropriate habitats, what results from increase of intensity of agriculture. The intensity of agriculture particularly increased in the 1970s and 1980s. The most serious threat was the increase in the nitrogen content in surface and groundwater. It resulted from increasing non-point pollutions of agriculture landscape and intensive nutrient leaching from dried up peatbogs. Both aquatic and marsh ecosystems are very important refuges for plant species and their communities which are the most vulnerable to human impact.

In recent years, probably as the result of temperature increase and eutrophication, increase of frequency of cyanobacterial toxin-producing blooms have been noticed in various water bodies [77]. Cyanobacteria are very expansive and their massive appearance, regardless if they produce harmful compounds or not, it is an unfavorable phenomenon. First of all, it is a sign of impaired balance of the ecosystem [78]. The effects of the cyanobacterial blooms are a large concentration of biomass, loss of biodiversity, reduction in biocenotic stability system, the presence of large numbers of heterotrophic bacteria (especially in the phase of cyanobacteria decay), inhibition of photosynthesis of planktonic algae which are associated with cyanobacteria as well as profound oxygen deficits in the lower layer of water column [79]. The most sensitive to cyanobacterial toxins are warm-blooded Vertebraters. 
Another threat for aquatic ecosystems biodiversity is an incorrect fishery management. For example, large stock of grass carp (Ctenopharyngodon idella) results in adverse changes in the littoral of aquatic ecosystems. This species eats vegetation, leading to the elimination of spawning areas of fish and fry regrowth of the native valuable species. Small bodies of water rich in grass carp may be completely devoid of vegetation.

Common carp (Cyprinus carpio) at high densities can significantly influence on environmental conditions, accelerating the rate of eutrophication of natural waters and the same have a negative impact on native fish species. The foraging behavior of carp can also negatively affect the structure and dynamics of benthic macroinvertebrates community, as well as the physical condition of the substratum [80]. These disturbances may also intensify the algal blooms due to the re-suspension of sediments [81] and release of nutrients [82,83]. Serious problem for biodiversity of aquatic environments and marshes results from overdrying of peatlands and changes in their management.

The transformations of vegetation in the Wyskoć Canal reflect in the eutrophication of waters and changes in water flow rate. Water management measures undertaken in the 1980s caused a lowering of both the river bed and water table of the ditch. As a consequence, there was observed drainage from surrounding meadows, what caused an accelerated peat mineralization and intensive leaching of nutrients. The observed transformations of reed and sedge communities in the Kościan Plain have partially natural and partially anthropogenic character, because the natural plant succession also accelerated due to the human pressure as well as due to climate changes, especially low precipitation. The increase in the number of identified plant associations is a result of human impact. However this process is jointed with withdrawal of plant species distinctive for waters with low nutrient concentrations and by expansion of plant associations that are indicators of high nutrient levels in waters.

The natural values of wet and marsh meadows that belong to the richest elements of the studied agricultural landscape are threatened not only by drainage but also by changes in the usage patterns. The extinction of these habitats results from the intensification of management (fertilization and sowing of common grass species) but on the other hand from the abandonment of meadows cultivation, which leads to a complete overgrowth of them by willow shrubs.

\subsection{Insects (above-ground insects and butterflies)}

As the importance of landscape (and habitat) for insect diversity was studied in the "Kościan Plain" in many various research projects, here we focus on a comparison between cultivated fields and small wooded patches (wide shelterbelts in that case). Such approach allows underlining the role of non-farmed habitats presence as a key factor for preserving high biodiversity level of an agricultural landscape. The results obtained during the last three years (2009-2011) show that the density, biomass, and diversity (expressed as number of above-ground insects families) in the shelterbelts are significantly bigger than in arable 
fields. Also in narrow ecotone $(0-0.5 \mathrm{~m}$ from the shelterbelt) higher values of those parameters were noted. Thus, the results showing differences in density, biomass and diversity of entomofauna, depending on shelterbelt's age, which were reported earlier [84, 85] have been confirmed. The highest values of those parameters were observed in young (several years old) shelterbelts, in early stages of ecological succession. The lowest diversity (47-61 families) was observed in the several years old shelterbelt and the highest diversity (63-74 families) in a few years old one. In the oldest (over 100 years old) shelterbelt moderate values were noted (58-69 families). Similar pattern was found for density and biomass of insects. Also in the ecotone zone these differences were similar, but they completely disappeared in the arable areas distant $100 \mathrm{~m}$ from the shelterbelt, values of studied parameters are much lower than in shelterbelts and ecotones (Figure 8). That pattern have been constant for many years (several decades), while the proportions were changing and during recent years the mean individual weight and biomass of insects in the open fields (away from shelterbelts) increased.
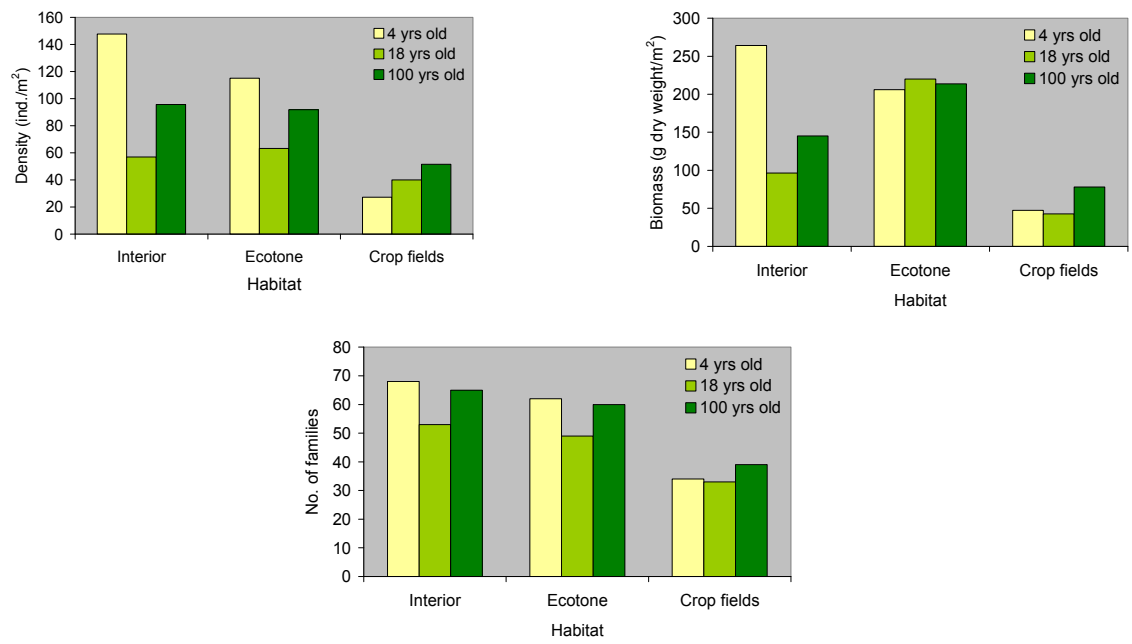

Figure 8. Relationships between insect communities (density, biomass, number of families) in vegetation season and age of shelterbelt with respect to three habitats: shelterbelt interior, ecotones between shelterbelt and cultivated fields and open fields.

The importance of non-farmed habitat for insect diversity was also studied in winter. As early as in fifth or sixth winter after introduction of the shelterbelts, they became an important place of wintering for numerous insect species. The diversity measured by the number of families reaches values (over 30 families) stable during next years of shelterbelt's growth (Figure 9). In the case of insect density, after rapid and strong increase of its value in 6th - 7th year of shelterbelt's growth (up to over 1300 ind. $/ \mathrm{m}^{2}$ ), some decline and stabilization at the level about 200-1300 ind. $\mathrm{m}^{2}$ was observed. Similar pattern of changes was noted for biomass. All studied parameters (density, biomass, number of families) reached the highest value in the oldest shelterbelt and the lowest - in the youngest one (Figure 10). 


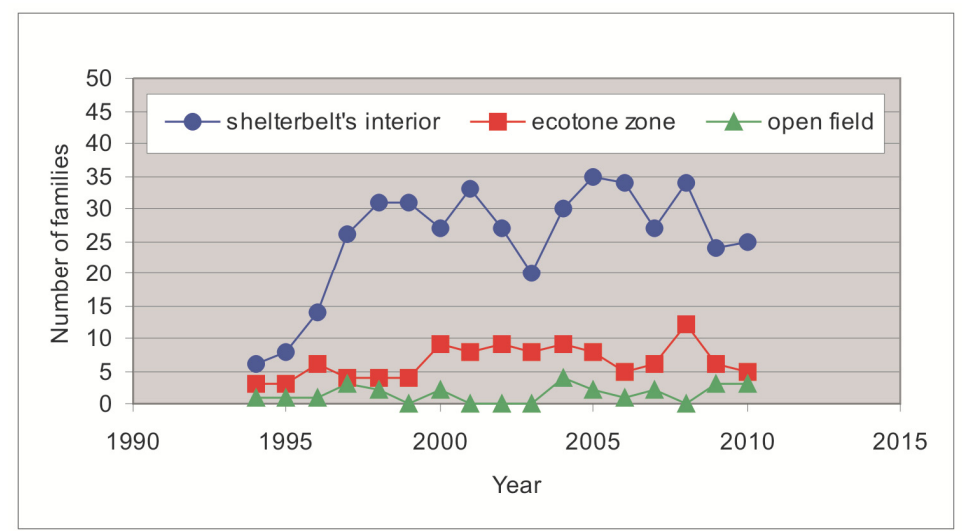

Figure 9. Number of insect families wintering in young shelterbelts and in adjacent crop fields.

Ongoing process of increasing share of cereals in crop structure creates favorable conditions for existence of species primarily living in grasslands, mainly steppes.

\subsection{Spiders}

Effect of landscape structure on spider assemblages is till now unclear and understanding it needs further investigations. However, gathered data also suggest positive effect of mosaiclike structure of landscape. Mean spider population density in cereal and sugar beet crops was similar across the landscape. In cereals it amounted to 7.5 ind. $/ \mathrm{m}^{2}$ in mosaic landscape ("Turew Mosaic Landscape") and 7.3 ind./ $\mathrm{m}^{2}$ in homogeneous landscape (in the "Kościan Plain"). In
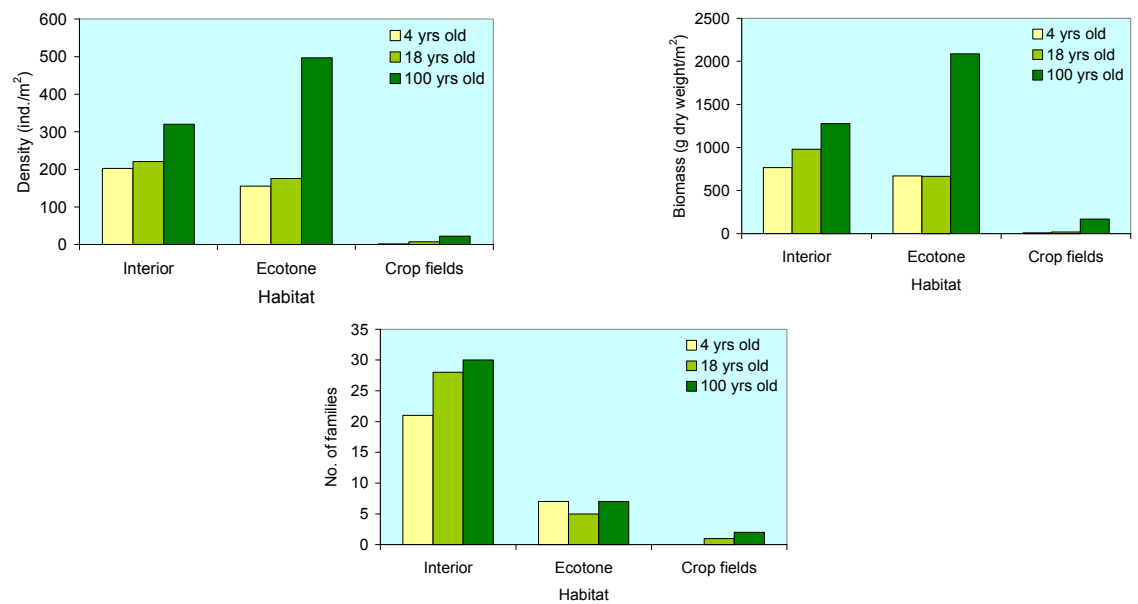

Figure 10. Relationships between insect communities (density, biomass, number of families) in winter and age of shelterbelt with respect to three habitats: shelterbelt interior, ecotone between shelterbelt and cultivated fields and open fields. 
sugar beet crop it was equal to 3.1 and 2.9 ind. $/ \mathrm{m}^{2}$, respectively. However, greater differences in alfalfa crop were noted. In homogeneous landscape spider density amounted 4.1 ind. $/ \mathrm{m}^{2}$ and in the mosaic one -10.8 ind $/ \mathrm{m}^{2}$.

Spider species diversity in cereal and alfalfa crops was near twice higher in the mosaic landscape than in the homogeneous one. On the other hand, in sugar beet crop the same numbers of spider species were stated in both landscapes. In all studied crops in homogeneous landscape aeronautic spider species (small-in-size Linyphiidae) were more abundant than in the mosaic landscape. Foliage-dwelling spider assemblages structure in the studied crops were more diversified taxonomically in the mosaic landscape - higher numbers of spider families (cereals) or species (sugar beet and alfalfa) were noted. Moreover, the differences in share of particular spider families were stated. Non-web spiders were more abundant in these assemblages: ambush (families Thomisidae and Philodromidae) as well as actively hunting ones: Pisauridae, Salticidae, Mimetidae and Lycosidae.

In the cereal crops situated in homogeneous landscape the vast majority (75\%) of the assemblage was composed of Araneidae - spiders hunting with orb webs, whereas in the mosaic landscape they constituted slightly more than $50 \%$ of the whole assemblage. In the last mentioned landscape type higher abundance of theridiid spiders was noted, which built three dimensional tangle webs. In the sugar beet crops the most abundant spider families were Theridiidae and Araneidae. The first one composed of over $40 \%$ of assemblage in the homogeneous landscape, and share of Araneidae was similar (45\%) in the mosaic landscape. Among foliage-dwelling spiders in alfalfa crops linyphiid spiders (in majority Erigoninae) composed of $60 \%$ of assemblage in the homogeneous landscape and $25 \%$ in the mosaic landscape. In the last one the next $25 \%$ composed of Araneidae. The share of families Theridiidae and Tetragnathidae was similar in both landscapes.

The crop fields adjacency to the shelterbelts resulted in increasing of spider species diversity in above-ground layer of all studied crops. In the distance of $10 \mathrm{~m}$ from shelterbelts the highest numbers of spider species were stated and with the increasing distance the species numbers decreased until near twice lower in $100 \mathrm{~m}$ from shelterbelts.

\subsection{Birds}

The "Turew Mosaic Landscape" was in 1991-1994 inhabited by 76 breeding species [59] as mentioned in the chapter 4.5.1. The number may be evaluated as relatively high in Poland when agricultural areas are considered and the study area size is taken into account (Figure 11A). Moreover, regression analysis (GLZ) showed, that number of years had no significant effect on total number of species in this set of data. Thus, the Figure 11A evidences for high bird species richness in the "Turew Mosaic Landscape", presumably as a pure (not methodologically-biased) effect of habitat quality. 


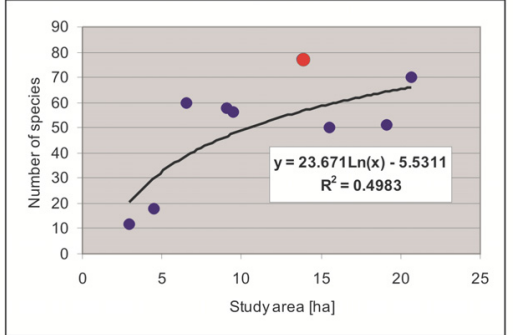

(a)

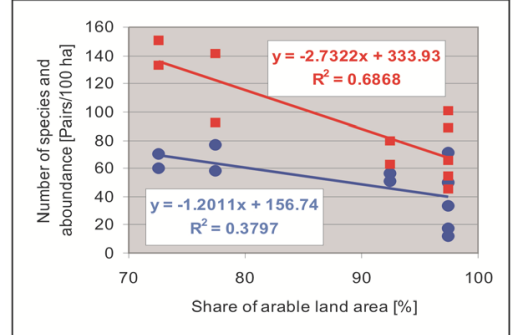

(b)

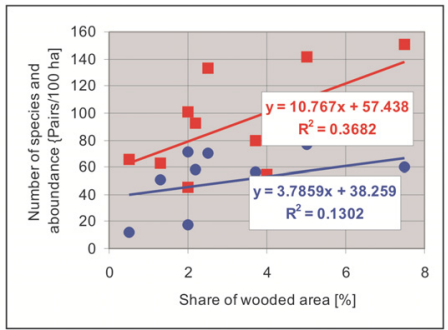

(c)

Figure 11. a) Species - area relationship for Polish farmlands [86]. Red dot - “Turew Mosaic Landscape"; b) Effect of cultivated fields share on breeding avifauna [86]. Red - species number, blue density; c) Effect of wooded patches share on breeding avifauna [86]. Red - species number, blue density

The data gathered and presented by [86] confirm clear relationships between landscape structure and bird richness and abundance. The values of both variables were negatively correlated with the share of arable land (Figure 11B) and positively correlated with the percentage of land covered by small wooded patches, lines etc. (Figure 11C). These two variables were weakly correlated $(\mathrm{r}=-0.43, \mathrm{p}=0.19)$, so presumably both influenced the avifauna independently. It is worth to underline that species number of bird community in the "Turew Mosaic Landscape" is as high as observed in Podlasie, in eastern part of Poland [87], which is characterized by much less intensive farming practices than in Wielkopolska region and one could expect higher bird species richness just in E Poland. What is more, the species composition similarity between the "Turew Mosaic Landscape" and Podlasie was high (incidence-based Sörensen index $=82 \%$, after [86], what indicates high efficiency of landscape structure (mostly wooded patches, lines etc. in that case) as a tool for mitigation of the impact of farming intensification on biota. Strong relationships between species richness and landscape structure is reflected also by the analyses performed for the data gathered in 25-55 ha subplots within the "Turew Mosaic Landscape" and in other places in Wielkopolska, which confirmed crucial importance of the saturation of the landscape with the wood patches and woodland-cropland ecotones [88]. 
The relationships between landscape structure and species richness (i.e. Jack-Knife 2) were studied with the use of the data from point count census presented by [89]. The analysis indicates similar overall species richness (65-80 species) in various landscape pieces with no respect to landscape structure (Figure 12), but the shape of estimated curves shows significant differences in species richness spatial distribution between the studied plots. In more simplified plots (arable fields $-95 \%$ ) it is necessary to visit $>25$ points to observe 60 species, while in most diverse (arable fields - 52\%) - only 15 points is needed to record 60 species It is also worth to underline that the landscape consisted of tree line, belts and patches (arable fields $-75 \%$ ) had similar overall species richness to the area (arable fields $52 \%$ ) with relatively big forest complexes (Incidence- and abundance-based Sörensen index amounted to $76 \pm 2 \%$ and $94 \pm 3 \%$ S.E, respectively).
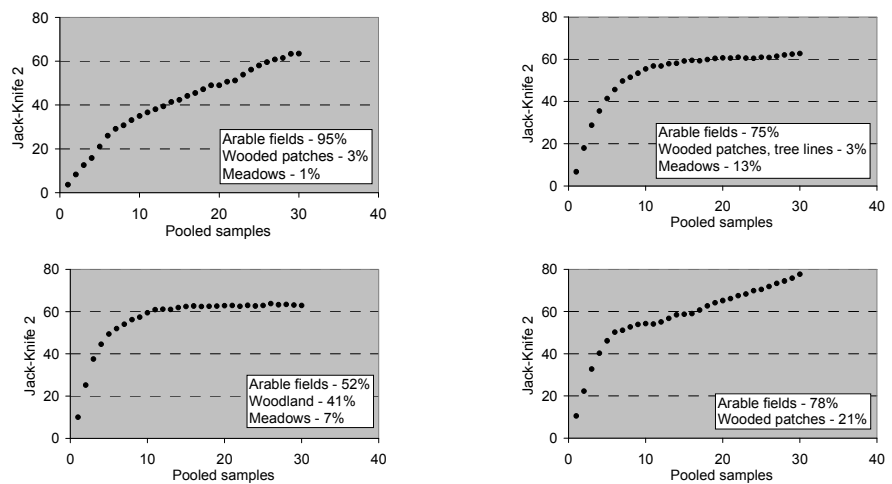

Figure 12. Bird species richness in various landscapes estimated with the use of Jack-knife 2.
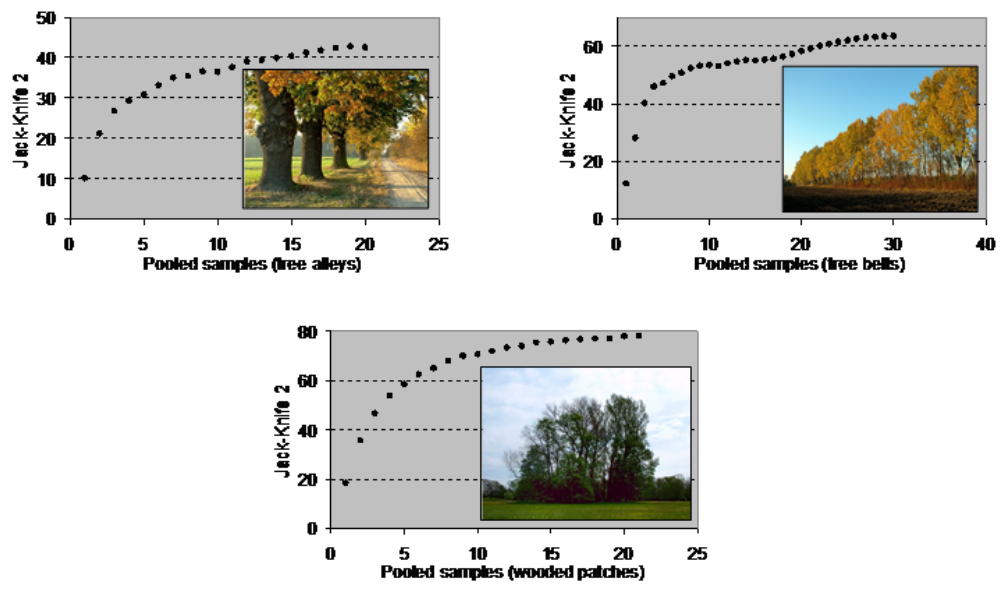

Figure 13. Bird species richness in various wooded habitats estimated with the use of Jack-knife 2. Photo K. Kujawa. 
Due to a study focused on birds in small wooded patches, it could be possible to study the relationships between the bird communities and the variability in habitat structure (i.e. in scale of several hectares). The first issue was studied in small wooded patches, tree lines etc. Using the data presented by [32], the highest potential overall species richness (ca. 80 species) was estimated for wooded patches (Figure 13) and the value is close to the total species richness estimated for all kinds of patches (clumps, belts and lines) built of woody species.

Observed differences may be surely related to the differences in habitat structure between the three wooded habitat types as the analyses presented by [32] showed crucial importance of such habitat features as tree stand age, percentage cover of tree and shrub layer and the area (or length in case of line habitat), which all influenced species number positively. Indeed, the differences in bird species richness were in line with the differences in habitat structure between three habitat types [32].

However, the knowledge on relationships between individual habitat structure usually allows for explaining only a part of bird community variability in wooded areas. The analyses performed for the data on 66 islands located in the "Turew Mosaic Landscape" showed that taking into account landscape structure around studied habitats allows for understanding avifauna variability much better, especially for species strictly related to woodland, for which positive role for small wood island colonization played the presence of other wooded patches and tree lines in close adjacency [33]. Seemingly, these habitats significantly reduce the open landscape "resistance" for migrating woodland species and, as a result they enhance probability of colonization of given wood island by the birds.

\subsubsection{Effect of land-use changes on bird communities}

The quantitative investigations on birds in various mid-field wooded patches were conducted for the first time in 1964-1966 and were repeated in some plots in the years 1984, 1991-1994 [32], 1999-2002 [33] and 2005-2006 [89]. During the last 50 years, farming practices have been much intensified thus gathered data on birds enabled for testifying the effect of farming intensification on birds. Uniqueness of that research relies on dissecting the effect of landscape structure simplification and the effect of farming intensification. Commonly in Europe, landscape homogenization follows the intensification of agricultural techniques, but not in the "Turew Mosaic Landscape", where the spatial arrangement of non-farmed habitats is stable (even enriched with new tree lines and belts recently) due to establishing the Dezydery Chłapowski's Landscape Park, which successfully protects historically formed land mosaics (see "Study area").

First analysis of long-term changes in the breeding avifauna in the "Turew Mosaic Landscape" was done by [90]. The number of breeding species has increased from 44 in the 1960s to 51 in the 1990s (which can be at least partially explained by somewhat bigger sampling effort in the later period).

Total density of breeding birds remained unchanged in wooded patches (23-24 pairs/ha) with obvious exception of few areas where tree stand was cut. However, there was noticeable decrease in population density of some 'farmland specialists' like corn bunting and ortolan bunting. The analyses were then concluded that although the structure of bird 
community has changed only slightly in the study area, the population trend analysis suggests that agriculture intensification affects the avifauna [90].

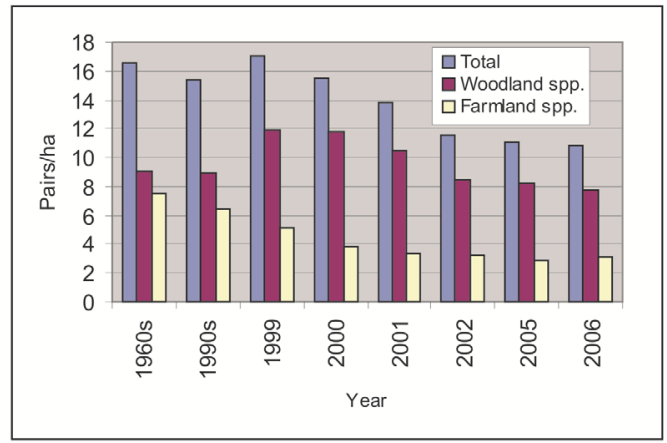

(a)

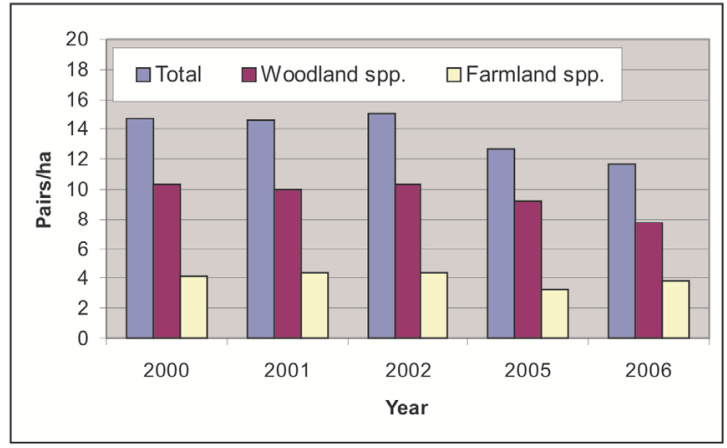

(b)

Figure 14. a) Bird population density in 6 wooded patches in the "Turew Mosaic Landscape" between 1964 and 2006 [90]; b) Bird population density in 55 wooded patches in the "Turew Mosaic Landscape" between 2000 and 2006 [90].

Recently, the changes that avifauna of small wooded patches is undergoing have been proved again [91]. The results of comparisons between the study periods (1960s, 1990s, 19992002 and 2005-2006) show large and significant different pattern of the changes for two main guilds of birds: woodland species (i.e. birds living in breeding season only in wooded areas, e.g. woodpeckers, robin Erithacus rubecula, nightingale, and spotted flycatchers Muscicapa striata) and farmland species (i.e. birds, which occur in wooded areas but using adjacent cultivated fields as feeding area or as place for building of nest, e.g. ortolan bunting, redbacked shrike, and goldfinch Carduelis carduelis). In the last 50 years the woodland species abundance and species number has been changing irregularly (increase in 1990s, some decline in XXI century), while the farmland species guild tends to decline permanently (Figure 14A). In consequence, the structure of the community has changed markedly. In 1960 s the share of farmland species amounted to $45 \%$, and it decreased in $2005-2006$ to $27 \%$. 
Recently some decline in species richness has been observed too. Mean number of species per wooded patch decreased from 8.6 \pm 4.3 (SD) to $7.5 \pm 3.9$ (SD) and bird abundance declined, too (Figure 14B). The differences between 2000-2002 and 2005-2006 were statistically significant for both guilds of species [91]. The observed pattern of changes shows that the intensification of agriculture is the main factor responsible for some bird impoverishment in small wooded patches in the "Turew Mosaic Landscape". Thus, it may be concluded, that mosaic of diverse habitat is necessary but not sufficient condition for successful protection of bird diversity in the agricultural landscape. To be as sufficient as possible, mosaics of diverse habitat has to accompany less intensive and more diversified (in terms of number of crops) farming.

\subsubsection{Factors influencing avian diversity}

The analyses and findings presented above show, that the bird communities in an agricultural landscape are influenced by a complex set of factors, which act in both habitat scale and landscape scale. The mechanisms involved are summarized below.

\subsubsection{Habitat scale}

- $\quad$ Patch size. The number of breeding species increases with the length and width of tree alleys and tree or hedge belts [32] and with the patch area [32,33]. Birds are highly plastic species. Many species is able to breed in very small-sized patches. As many as 45 species were found to nest in wooded patches smaller than 1 ha [33].

- Patch shape. More complicated shape affects positively total species number as favors species preferring ecotonal and woodland edge species [33].

- Patch vegetation structure. More species breed in wooded patches with deciduous species, with old, diverse tree stands, with higher percentage cover of shrub layer, which means that more rich in species are wooded patches similar in structure to natural forest typical (but rarely occurring) for lowland regions in moderate climate [32, 33].

- Diversity of crop fields. This factor affected not only the number of species breeding in open area (more species in more fragmented and more diversified cultivated area) but also the birds occurring is small wooded patches (bird abundance and species number higher when the patch surrounded by diverse, fragmented crop fields) [33].

\subsubsection{Landscape scale:}

- Landscape context (for wooded patches). Although isolation of studied was on average small (distance from woodland amounted to maximum few kilometers, presence of dense network of tree line and belts) some bird species, especially those typical to woodland) were more abundant in wooded patches, which were located in a landscape rich in other wooded patches [33]. It means, that the knowledge on relationships between birds and inside habitat structure is not enough to understand the distribution of birds. It is necessary to take into account the landscape structure as well.

- Landscape heterogeneity. The analysis of species richness indicates that avian diversity in a mosaic-like agricultural landscape may be kept at same level as in a landscape with high 
woodland dominance (in case of considering managed forest). If we take into account, that avifauna in our study included also rare and protected species (with abundant populations of e.g. Ortolan Bunting, Corn Bunting), the conclusion clearly arise that key way for preserving high bird species richness is making landscape as heterogenic as possible. Even though non-farmed elements cover only $5-7 \%$, it is enough to preserve almost all species from the woodland generalists and woodland edge species. The observation can me generalized with respect to the issue of fragmentation. Although in ecology the habitat fragmentation is considered as negative phenomenon, in agricultural landscape that process has rather positive role for species diversity, when we discuss about small ( $<10 \mathrm{ha}$ ) forest patches. Concluding with the use of simple, model example, it is more profitable to keep e.g. five forest islands with the area 3 ha each, connected to each other by several kilometers of tree belts, than one "large" forest island with the area of 20 ha.

The studied area, especially the "Turew Mosaic Landscape", is characterized by most of features listed above. There are numerous, diverse non-farmed habitat patches bodies and wetlands. Moreover, most of wooded patches have old tree stand, they have diverse vegetation structure. Due to these features and mosaic-like structure, the "Turew Mosaic Landscape" constitutes a distinct example of an agricultural landscape, in which relatively rich avifauna occurs despite of high agricultural pressure [86]. Such agricultural landscape is favorable for at least 100 species, i.e. ca $40 \%$ of breeding species observed in Poland. It is striking number and we claim that the "Turew Mosaic Landscape" may play a role of a reference point for the studies on diversity of birds in lowland agricultural landscape in Central Europe.

However, recent publications on long-term changes in avifauna showed that even strongly stable amount and arrangement of non-farmed, semi-natural habitats is not enough to effectively preserve species richness, when farming practices become more and more intensive. Long-term decline in ecotonal species populations [89, 90] clearly show, that stable amount and structure of wooded patches, tree lines and tree belts does not mitigate the effects of farming intensification for all bird species guilds. Farming extensification seems to necessary to preserve total bird diversity.

\subsection{Fungi}

In chapter 4.7.1 it was mentioned that $26 \%$ of species observed in the "Kościan Plain" study area belong to the group of special concern species (Species protected by law, threatened species listed in "Red list of the macrofungi in Poland", threatened species listed in "European red list of the macrofungi", rare species).

Occurrence of these species in the study area provides great facilities in protection of fungal diversity in Poland (including agricultural area), due to proper landscape management and planning. Moreover, it may be useful for evaluation of response of given species to habitat alteration as well as for elaboration on nationwide strategy for protection of rare and threatened (according to IUCN's criteria) species of fungi. Proper landscape structure has significant influence on species diversity of fungi all over Poland. It allows for surviving of many woodland species under strong, unfavorable human pressure. Additionally, some rare 


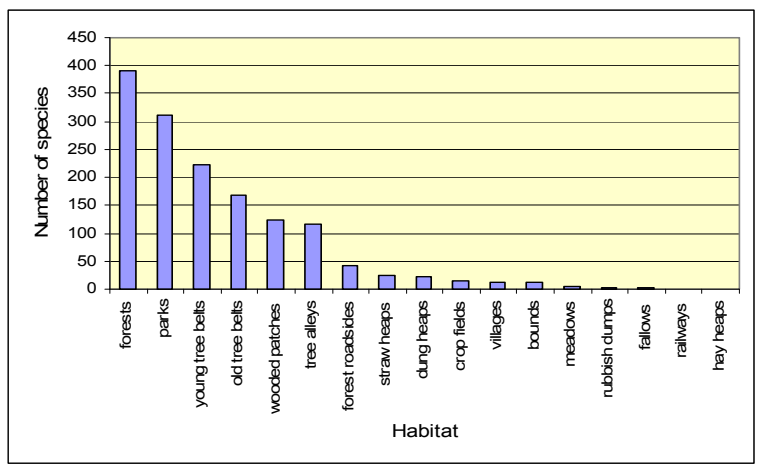

Figure 15. Number of fungi species in habitats located in the "Kościan Plain".

species dependent on traditional agriculture (growing in pastureland or organically fertilized fields) find appropriate niches in strongly diversified, mosaic agricultural landscape.

A key component for incorporating natural enemies, including fungi, in pest management in sustainable farming is the application of appropriate agricultural practices that improve conditions for these organisms in the agroecosystems and surrounding habitats. Agroecosystems suffer from mechanical disturbances due to necessary tillage regimes of various kinds, and these practices may negatively affect occurrence of entomopathogenic fungi in the soil $[92,93]$. This was confirmed in [72] studies conducted in the years 2002-2004 in the area of Borek Wielkopolski directly adjacent to the "Kościan Plain".

\section{Impact of climate change}

Impact of climate change on biodiversity can be both direct and indirect. The direct influence lies in the fact that climate change will lead to changes in habitat conditions (mainly temperature and moisture) that can be favorable for some species and unfavorable for others. This influence is revealed by disappearing of existing species and by appearing of alien species, among which some can be invasive. The indirect impact is the fact that changes in habitat conditions are forcing farmers to change cropping patterns. For example, growth of thermophilic plants that require less rainfall (increase of cereals at the expense of root crop cultivation). This in turn influences the change of plant community and animals living in the agricultural landscape.

There is no doubts that climate change is not new in geological history of Earth, and organisms have adapted to most serious changes over evolutionary timescales. But the key question today is how will organisms respond to the current apparently rapid rate of anthropogenic climate change? [94].

Kędziora defined the process of climate changes that occurred in Poland as mediterraeanization. It's expressed by gradual increase of average air temperature with simultaneous absence of annual precipitation increase and move rainfalls to cold months. Similar trend for climate changes was observed in the neighboring state of Brandenburg. Such course of changes leads to deterioration of higrothermic conditions, especially during vegetative season. 
It is obvious that impact of climate and land use changes is working synergistically. Therefore, the analysis of changes of land-use in the landscape during long period has been done in order to to distinguish the impact of climate from the impact of land use,. The study of a landscape structure which was conducted in the area of $16 \mathrm{~km}^{2}$ in the vicinity of Turew, where the total area of meadows, pastures, and woody vegetation patches (the most important ecological elements in the agricultural landscape) was assessed at four time horizons: 1890, 1940, 1989, and 1996. Share of meadows, pastures and woody vegetation in total area of the landscape showed significant increase in the period $1890-1940$ and remained slightly changed in the period 1940 - 1996 (Figure 15A). Although only mild increase of tree patches (from 64.5 to $69.5 \%$ ) and decline of tree lines (from 35.2 to 30.5) and small decline of pastures was observed during the period 1940-1996 (Figure 15B), disadvantageous trend of changing their distribution occurred: disappearance of single trees and small strips of meadows distributed between fields [44].

Simplification of agricultural landscape may not only occur together with climate change, but it can also be a result of those changes. Deterioration of hydrothermal condition may cause disappearance of moist habitats, like swamps, marshes, and bogs. The presence of ecologically differentiated water reservoirs in landscape is also the key factor for maintenance of amphibian populations. Protection of such habitats in the agricultural landscape is especially difficult because this area is usually very (sometimes extremely) small and particularly vulnerable to influences. But the most important change, threatening biodiversity, is observed in the structure of the crop. Area of cereal crops increases rapidly at the expense of perennial and root crops. Until 1990s, [95] reported following structure: cereals 50\%, row crops (including rapeseed) $20 \%$, perennial fodder crops $10 \%$ and others $20 \%$, in first decade of $21^{\text {st }}$ century [96] noticed: cereals (including maize) $78 \%$, legumes $16 \%$, potato, rapeseed and sugar beets $6 \%$.

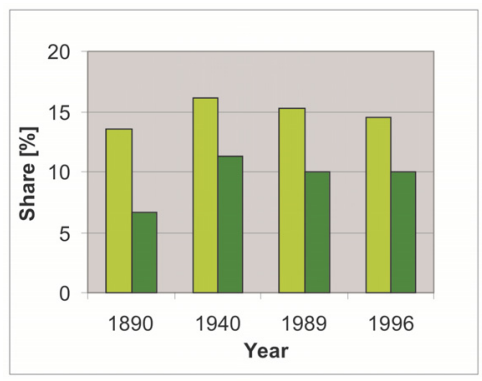

(a)

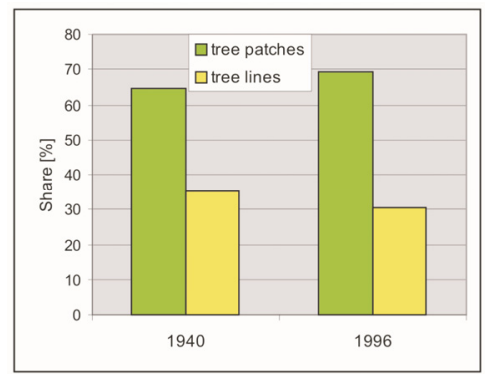

(b)

Figure 16. a) Changes of share of meadows and pastures (light green) and woody vegetation (dark green) in total area of investigated landscape [44]; b) Changes of share of tree patches (light green) and tree lines (yellow) in total area of woody vegetation in investigate area [44].

In global scale temperature increase may cause serious changes in species distribution which will expand their ranges towards higher latitudes. Such processes were just observed in the case of fungi and lichens in UK, Netherland and Baltic See region. Herk [97] found, basing on a long-term monitoring, that many tropical and subtropical species of epiphytic 
and terrestrial lichen species are invading the Netherlands while $50 \%$ of the arctic-alpine and boreomontane species already shows a decline. In Baltic See basin, 39 distinguished species of Macromycetes extends range to the northern latitudes, for example from Central Europe to Scandinavia [98, 99]. Expected dramatic decline of forests and tundra biome towards desert and grasslands. This prediction was supported by [100]. Some results in literature, especially these made on climatic transects [101] showed that in many regions of the world we should expect increase of $\alpha$ diversity (species or highest taxonomic units number) as climate change will progress [102]. On the other hand due to dramatic speed of change we will lose mainly vulnerable species with narrow ecological niches $[103,104]$. Such species are rare and characteristic for unique regions or habitats [105]. But then again common species having wide amplitude of distribution will move towards highest latitudes [106]. Increasing ranges of alien species might mean also the invasion of pests, both animals as fungi. Widely known is the case of Harlequin frog in mountain areas of tropical Central America (Monteverde (Costa Rica)). [107] showed that ongoing global warming process changes microclimate condition of Monteverde (Costa Rica) towards optimum for chytrids (warmer nights and increased daytime cloud) (Batrachochytrium dendrobatidis). This fungi infects amphibians causing Chytridiomycosis - an infectious disease of amphibians responsible for extinctions of amphibian species in western North America, Central America, South America, eastern Australia, and Dominica and Montserrat in the Caribbean. Classic example is also horse chestnut leafminer (Cameraria ohridella - invasive species of uncertain origin, first observed in Macedonia in 1984 [108]. Pest invaded central and western Europe at an approximate rate of $60 \mathrm{~km}$ year. In Poland the species was discovered in 1998 for the first time in Lower Silesia [109]. The march of this insect, from south west to north east (according to the line of spring progress in Poland) suggests that its expansion is connected with climate changes. As far as plants are concerned changes in species distribution may lead to disturbances of balance between plants with different photosynthetic pathways. The system of interrelated factors influencing photosynthesis $\left(\mathrm{CO}_{2}\right.$, temperature, water availability) is very complicated and it is difficult to predict the direction of changes. For example, the increase of $\mathrm{CO}_{2}$ concentration in the atmosphere will stimulate $\mathrm{C} 3$ plants [110113] while in the case of $C 4$ plants, biomass growth and competitive potency will be stimulated by temperature increase. Apart from that, $\mathrm{C} 4$ plants have better efficiency of water use (WUE) [114]. Therefore deterioration of humidity conditions caused by increase of temperature will cause better conditions for $\mathrm{C} 4$ plants than for $\mathrm{C} 3$ plants. Last observations suggest that despite of $\mathrm{CO}_{2}$ elevation we may expect increasing share of $\mathrm{C} 4$ plants, in Central Europe. For example, between 372 species of exotic plants in Poland until 7.5\% (28) consist C4 plants, while in native flora of Poland only 5 species represent C4 photosynthetic pathway. Some of them are aggressive invasive plants, (genus: Setaria, Digitaria, Echinochloa, Eragrostis, Amaranthus,). Many of them are common weeds, brought to the area before industrial era, with the crop plants, originated from the Middle East, but presently occurring of these species are not restricted to crop fields, some of them (Echinochloa crus galli, Amarantus retroflexus, different species from Eragrostis genus are aggressive invasive plants.

Changes in entomofauna of agricultural landscape, observed in last decades, are probably an effect of global climatic changes (since eighties). Increase of temperature without increase of precipitation, especially in summer is favorable for termophilous species. There are 
herbivorous species among them, so they are potential or real pests, mainly some of the beetles, bugs and butterflies. Several years ago, chemical protection from genus Eulema, strongly exceeding so-called threshold of harmfulness, started to be applied. Near this threshold there are tortoise bugs (Eurygaster), cutworms (Agrotis) and cereal ground beetle (Zabrus tenebrioides). The last species is an imposing beetle (family: Carabidae), feeding (larvae and adult forms) on cereals. High density of beetles may cause considerable loss, when they climb to ears and eat grain. In the last decade, number of Thysanoptera has also instantly grown. In 2002, in Wielkopolska region, they exceeded the harm level (mainly on oat). They were not chemically exterminated, and in last decades they were considered as potential pests Significant increase of Simulidae has also been observed. In the 70's and 80's years, only single individuals were found in large samples, containing several thousands of other Diptera, taken by motor net [25]. Increasing number of south-european (Mediterranean) species, especially moths (Sphingidae, Noctuidae) and Cicadidae, e.g. Cicada orni has been observed. For several years, the invasion of Asian ladybugs (Harmonia axyridis), is also observed.

The number of alien insect species will probably grow up. Some of them, with high invasive potential, are already present here, e.g. agrofagical western corn rootworm (Diabrotica virgifera), recorded in Poland since 2005. It is hoped that those species can not reproduce on a mass scale, because of natural, regulating biocenotic processes which efficiently act in an agricultural landscape. Such effect concerning horse chestnut leafminer (Cameraria ohridella) has been observed since the begin of the present century. Number of natural predators of this species grows from year to year and the presence of this pest decreases, what can be easily observed. On the contrary, 20-years study on insect fauna in Turew landscape showed graduating changes in its structure. During this period mean individual body mass of insects increased significantly (Figure 17A) as well as total biomass of insect community (Figure 17B). However biodiversity (expressed by number of families) significantly decreased much quickly in uniform landscape than in mosaic (Figure 18). This is probably an effect of the increase of the number of xerophillic and thermophillic insects on arable fields, including invasive large agrophagus, not connected with seminatural parts of agricultural landscape (Zabrus, Agriotes, Eulema, and Eurygaster) and predators (Nabis).

This phenomenon is a result of synergetic impact of increasing of cereal area and climate changes which leads to invasion of alien species having high body mass. Investigation showed that after 1990s a new species of butterflies have been observed. These species originated mainly from south and east Europe where climate is more dry and warm. It were thermofilic and xerophilic. For instance: Ephesia fulminea, Syntomis phegea, Catephia alchymista, Arcthia villica and more frequency inflying Mediterranean species (Macroglossum stellatarum, Agrius convolvuli, and Phlogophora meticulosa). Similar changes have been observed in other groups of insects (coleoptera, homoptera, hymenoptera, and heteroptera. Increase number of these species is especially evident in agrocenosis in uniform landscape, so diversity of insects living in cereals decreases slowly than in the mosaic landscape (Figure 18). Increasing share of maize in crop structure, which is the effect of climatic changes, brought about occurrence many efemeral habitats, like silage heap, which causes that some forest species migrates into agricultural landscape. For example: european rhinoceros beetle (Oryctes nasicornis) 
Another change in insect community structure observed during 20 years was gradual vanishing of differences between communities in two type of landscape. In the eighties, mosaic landscape was characterized by higher biomass, higher individual body mass of insects and higher number of families. In first decade of 21st century those differences vanished and number of families in uniform landscape was even higher then in mosaic landscape. These data suggest declining role of landscape structure together with progress of climate change and simplification of crop structure. Long term study of bird assembles in Turew area confirms the results concerning insects. Since1964 up to 2006, in birds assembles in afforestations in gen. D. Chłapowski Landscape Park number of species declined of 20$25 \%$, and this trend begun in the end of 20th century. Furthermore, permanent decrease of density of birds which use of agricultural fields during breeding period and typical forest species in 21st century (preceded by increase at the end of 20th century) has been observed. Comparison of the above results concerning birds rarely occurring in shelterbelts and hedges, typical for agricultural landscape with study results carried out 10 - 40 years ago leads to conclusion that farmland avifauna decreased approximately by 30 to $40 \%$.

Data collected at the beginning of this century, together with those which were collected earlier indicate that the population density and species richness in the group of species living in afforestations, but using agricultural fields are decreasing, and this decrease albeit has been slowly is continued for many years. Moreover, recent data (from the years 20002006) indicate that the forest species begin to acquire negative changes. This is a new phenomenon, because so far the forest birds were at least stable, both in density as species richness, and in some periods showed even upward trends. It is hard to explain, but it should be emphasized that the phenomenon of declining of some species typical to forest, even common, like poor tit, robin and creepers, was noted also in the country scale [115].

In present climate change conditions amphibians are especially vulnerable animal group. The simplest measure of the scale decreasing amphibian population is change in number of water reservoirs as amphibian breeding sites through years. Probably the first time in Europe this method was used by Danish, which made the picture of changes in amphibian populations in years 1940-86 [116, 117]. In the Wielkopolska region in the end of 19th century there were 11068 small water bodies (area less than 1 ha), but in 1960 only 2490 remained - decrease by $77 \%$ [118]. This process is ongoing. In the "Turew Landscape" between year 1960 and 1995 disappeared 55 out of 287 (19\%) small reservoirs. The main causes of this process were direct impacts of man activity, such as drainage and filling 36 artificial reservoirs, but disappearance of remaining 19 reservoirs $(35 \%)$ was caused by climatic changes - low precipitation and lowering of groundwater level [29].

Disappearance of these reservoirs together with biological degradation of many other caused decreasing of abundance of many amphibian populations (even up to 55-95\%), total disappearance of some other ones and drop of their diversity. The examples of such "climatic disasters" in Turew landscape are three large ponds situated in forest, far away from agricultural drainage system. All of them belonged in mid 1990s to the 10 most important amphibian breeding sites [28]. Pond 1 (Rabinek forest - 0,4 ha in 1988) - after lowering of water level number of water frogs droped from 1330 (in 1988) to 320 (in 1997) 


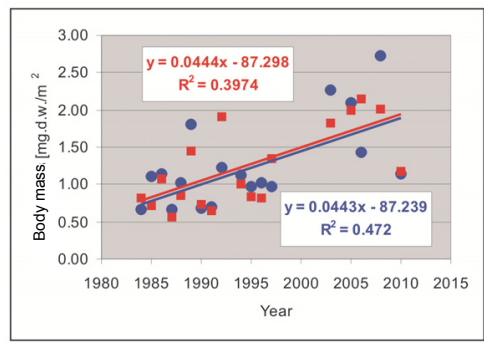

(a)

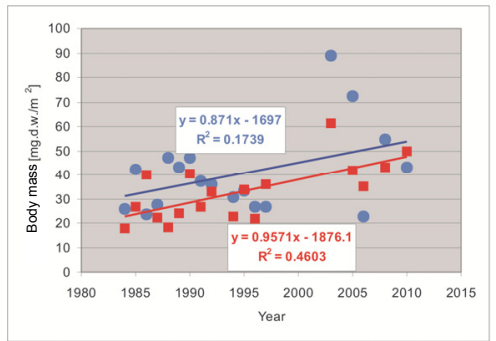

(b)

Figure 17. a) Individual body mass of epigeic insects on grain crops in two types of landscape; b) Total biomass of epigeic insects on grain crops in two types of landscape.

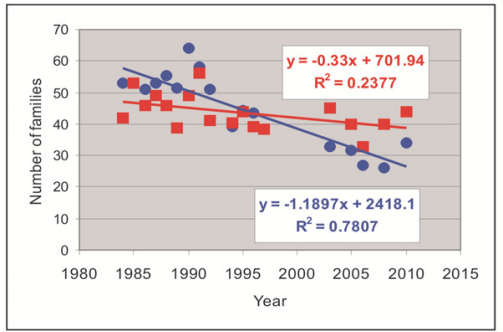

Figure 18. Diversity of epigeic insects (number of families) on grain crops in two types landscape.

individuals [51] at present there are ca. 50 frogs. Pond 2 and 3 (Błociszewo forest -4 and 1,3 ha in 1995) - two biggest forest ponds in the Turew landscape inhabited by the largest populations (more than 100 individuals) of two amphibian species from Appendix II of the EU Habitat Directive: crested newt (Triturus cristatus), fire-bellied toad (Bombina bombina) and European tree frog (Hyla arborea). In the beginning of the 21st century these ponds were completely dried up and all amphibians disappeared.

In conclusion: long term observations evidenced that changes lead to uniformization of flora, fauna (and probably funga) of agricultural landscape. We cannot precisely distinguish changes caused by landscape (and crop) structure simplification and those caused by global change but there is no doubt that agricultural landscape diversity deteriorates. In recent 20 years it became obvious that we cannot stop decline of biodiversity only by use of protection of landscape heterogeneity, because the scale of changes in crop structure and that which are not directly connected with landscape, e.g. climate change or in the case of birds occurring in wintering areas is too high.

\section{Conclusions}

It seems obvious that human activity transformed nature in pursuit of safe food supplies, assertion of more comfortable housing conditions, exploitation resources and making transportation of people and goods easier and so on. The main change is transformation of 
stable ecosystems like forests, meadows, wetlands into unstable, mainly in farmlands. In order to obtain high yields, farmers must eliminate weeds, control of herbivores and pathogens, ensure that nutrients are easily accessible only for cultivated plants during their growth, increase mechanization efficiency. To increase production, farmers simplify plant cover structure both within cultivated fields (selection of genetically uniform cultivars and weeds elimination) and within agricultural landscape (elimination of hedges, stretches of meadows and wetlands, small mid-field ponds). Animal communities on cultivated fields are also impoverished (Karg and Ryszkowski 1996). Negative ecological effects of agriculture intensification are connected to:

- $\quad$ impoverishment of plant and animal communities

- decrease of humus resources

- decrease of capacities for water storage

- increase of pollution from non-point sources.

It must be clearly said that although farmers can moderate the intensity of these processes through proper selection of crops and tillage technologies, they are not able to eliminate them entirely. The higher control environmental threats efficiency evoked by agriculture could be achieved by structuring agricultural landscape with various non-productive components like hedges, shelterbelts, stretches of meadows, riparian vegetation, small ponds and so on. Therefore, any activity taken in order to maintain or increase landscape diversity is important not only for aesthetics and recreation reasons, but even more for environment protection, and by the same for the protection of living resources in the countryside. But it has been found that in a mosaic landscape composed of cultivated fields, rich in shelterbelts, stretches of meadows, small ponds and other semi-natural elements of landscape, appear animal communities richer and more diversified plant than in a uniform landscape that is composed only of large fields [34].

In order to maintain and even increase biodiversity we should act in two directions. First is the preservation and restoration of degraded habitats to ensure the existence of many species of plants and animals. Second, enriching crop structure in plants which less important from an economic point of view, but important as refuges for many animal species.

\section{Guidelines}

There is a growing body of ecological knowledge that management of agricultural landscape for its structural diversity becomes the important pillar of the sustainability of rural areas. Program of environmental protection in rural areas should aim not only at the introduction of environmental friendly technologies of cultivation within farm. They should also be concerned with challenge of how to increase the resistance or resilience of the whole landscape against threats. This could be achieved by stimulating natural processes underpinning the control of diffuse pollution and erosion, increase efficiency of water retention and biodiversity conservancy, which can not be controlled only at the farm level but have to be managed by increasing the landscape structure diversity. 
The spatial net rangelands and shelterbelts in landscape of cultivated fields usually allows us to lower the concentration of harmful substances in environment to the level that is not dangerous for people's health and the normal course of natural processes. Understood this way, biogeochemical barriers constitute at the same time a kind of "shelters" for all living organisms. Thanks to this, they can influence, in a very positive way, the shaping and protection of the biodiversity in agroecosystems and agriculture landscape.

This does not mean that environmentally friendly technologies are not important. On the contrary, environment friendly technologies could mitigate negative effects of production but cycling of water or spreading pollution with water and wind operate in much larger scales than farm. It is also true for modification of microclimatic conditions or protection of biodiversity. The larger spatial scale e.g. watershed enables diversification of landscape structures which support higher stability and resistance of total landscape including individual farms to threats induced by production intensification.

The above considerations lead us to conclusion that activities aiming at optimisation of farm production and environment as well as biodiversity protection should be carried out in two different but mutually supportive directions. The first one involves actions within the cultivated areas. Their objective is to maintain possibly high level of the storing capacities of soil and to preserve or improve its physical, chemical and biological properties. They include agrotechnologies, which increase humus resources or counteract soil compaction, and rely on differentiated crop rotations. An important effect of humus resources augmentation would be improved water storage capacity, more intensive processes of ions sorption etc. Integrated methods of pest and pathogen control and proper dosing of mineral fertilisers adapted to crop requirements and to chemical properties of soil allow to diminish to same degree non-point pollution. The effectiveness of so directed activities, which could be called methods of integrated agriculture, depends on good agricultural knowledge.

The second component of the integration programme of farm production and nature protection is the management of landscape diversity. It consists in such differentiation of the rural landscape as to create various kinds of so -called biogeochemical barriers, which restrict dispersion of chemical compounds in the landscape, modify water cycling, improve microclimate conditions and ensure refuge sites for living organisms. In landscapes having mosaic structure higher doses of fertilisers can be applied than in homogenous ones which are composed of arable fields only (Ryszkowski 2002). This is a very important conclusion for the program of sustainable development of the countryside. Implementation of those ecological guidelines into the integrated agriculture policy will help to develop new environment friendly agro-technologies which, at the same time, enable intensive production balanced with ability of natural systems to absorb side effects of agriculture without being damaged.

Long term investigation carried out by Institute for Agricultural and Forest Environment showed that increasing complexity of agricultural landscape mainly by introduction of non- productive elements like shelterbelts, strips of meadows, bushes and small midfield ponds is one of the best tool for controlling water cycling and chemical pollution of surface and ground water in agricultural landscape. 
Such findings open new frontiers for conservancy of living resources outside protected areas and open new prospects for reconciliation of agriculture with nature protection. Paradigms that are presently in force should be changed as follow:

\begin{tabular}{|l|l|}
\hline Present paradigms & Future paradigms \\
\hline Conservation & Management of protected ecosystems \\
\hline Protection by isolation & Reconciliation with economic activities \\
\hline Species and communities & Ecosystems \\
\hline $\begin{array}{l}\text { Inventory of species and recognition of } \\
\text { their adaptations to environment }\end{array}$ & $\begin{array}{l}\text { Understanding life supporting processes } \\
\text { (energy flows, matter cycling and their control } \\
\text { mechanisms, transmission of information) }\end{array}$ \\
\hline Rare, endangered or protected species & Guilds or functional groups, key stone species \\
\hline Homogeneity & Heterogeneity (diversity) \\
\hline
\end{tabular}

Table 4. Conclusions

\section{Author details}

Andrzej Kędziora, Krzysztof Kujawa, Hanna Gołdyn, Jerzy Karg, Zdzisław Bernacki, Anna Kujawa, Stanisław Bałazy, Maria Oleszczuk, Mariusz Rybacki, Ewa Arczyńska-Chudy, Rafał Łęcki, Maria Szyszkiewicz-Golis, Piotr Pińskwar, Dariusz Sobczyk and Joanna Andrusiak Institute for Agricultural and Forest Environment, Polish Academy of Sciences, Poznań, Poland Cezary Tkaczuk Siedlce University of Natural Sciences and Humanities, Siedlce, Poland

\section{Acknowledgement}

Authors thank Mrs. M. Sc. Wenesa Synowiec for ensuring linguistic correctness of our elaboration.

\section{References}

[1] Dalesman R, F (1968) A Different Kind of Country. MacMillan Company, New York.

[2] Soulé ME, Wilcox BA (1980) Conservation Biology: An Evolutionary-Ecological Perspective. Sunderland, Massachusetts: Sinauer Associates Inc. 395 p.

[3] Millennium Ecosystem Assessment (2005) Washington DC: Island Press.

[4] Bourdeau P (2001) Biodiversity. In: Tolba MK, editor. Our Fragile World. Oxford: EOLSS Publishers. pp. 299-308.

[5] Kędziora A (2010) Landscape Management Practices for Maintenance and Enhancement of Ecosystem Services in a Countryside. Int. J. Ecohydrol. Hydrobiol. 10 (2-4), 133-152.

[6] Ryszkowski L, Karg J, Kujawa K, Gołdyn H, Arczyńska-Chudy E (2002) Influence of Landscape Mosaic Structure on Diversity of Wild Plant and Animal Communities in 
Agricultural Landscapes of Poland. In: Ryszkowski L, editor. Landscape Ecology in Agroecosystems Management. Boca Raton: CRC Press. pp. 185-217.

[7] Tryjanowski P, Hartel P, Baldi A, Szymański P, Tobółka M, Goławski A, Konvicka M, Hromada M, Jerzak L, Kujawa K, Lenda M, Orłowski G, Panek M, Skórka P, Sparks TH, Tworek S, Wuczyński A, Żmihorski M (2011) Conservation of Farmland Birds Faces Different Challenges in Western and Central-Eastern Europe. Acta Orn. 46: 1-12.

[8] Ryszkowski L (2000) The Coming Change in the Environmental Protection Paradigm. In: Crabbe P, Holland A, Ryszkowski L, Westra L, editors. Implementing Ecological Integrity. NATO Science Series, Vol. 1. Dordrecht: Kluwer Academic Press. pp. 37-56.

[9] Marcinek J (1996) Soil of the Turew Agricultural landscape. In: Ryszkowski L, French NR, Kędziora A, editors. Dynamics of Agricultural Landscape. Poznań: PWRiL. pp. 19-27.

[10] Palmer MW (1991) Estimating Species Richness: The Second-order Jackknife Reconsidered. Ecology 72: 1512-1513.

[11] Gołdyn H (2009b) Effect of Landscape Structure on the Floristic Diversity of Farmland: a Case Study of the General Chłapowski Landscape Park [in Polish]. Rozprawy Naukowe 403. Poznań: Uniwersytet Przyrodniczy w Poznaniu. 197 p.

[12] Matuszkiewicz W (2001) Guide to Estimation of Plant Associations of Poland [in Polish]. Warszawa: PWN Sci. Publ. 537 p.

[13] Pysek P, Richardson DM, Rejmánek M, Webster GL, Williamson M, Kirschner J (2004) Alien Plants in Checklist and Floras: Towards Better Communication Between Taxonomists and Ecologist. Taxon 53: 131-143.

[14] Lambdon PW, Pysek P, Basnou C, Hejda M, Arianoutsou M, Essl F, Jarošík V, Pergl J, Winter M, Anastasiu P, Andriopoulos P, Bazos I, Brundu G, Celesti-Grapow L, Chassot P, Delipetrou P, Josefsson M, Kark S, Klotz S, Kokkoris Y, Kühn I, Marchante H, Perglová I, Pino J, Vila M, Zikos A, Roy D, Hulme P (2008) Alien flora of Europe: Species Diversity, Temporal Trends, Geographical Patterns and Research Needs. Preslia 80: 101-149.

[15] Jackowiak B (1990) Anthropogenic Changes of the Flora of Vascular Plant of Poznań [in Polish]. Poznań: Adam Mickiewicz University Press. 232 p.

[16] Mirek Z, Piękoś-Mirkowa H, Zając A, Zając M (2002) Flowering Plants and Pteridophytes of Poland. A Checklist. Kraków: W Szafer Institute of Botany, PAS. 442 p.

[17] Szyszkiewicz-Golis M (2004) Structure and Functional Evaluation of Midfield Afforestation in Agricultural Landscape of Greater Poland Region - Row Wyskoc Catchment's Case [in Polish]. PhD thesis. Poznań, Agricultural University. 188p.

[18] Gołdyn H, Arczyńska-Chudy E, Pińskwar P, Jezierska-Madziar M (2008a) Natural and Anthropogenic Transformation of Water and Marsh Vegetation in Lake Zbęchy (Wielkopolska Region). Ocean. Hydrob. Studies 37: 77-87.

[19] Gołdyn H (2009a) Changes in Plant Communities of a Drainage Ditch Over the Last 30 Years. EJPAU Seria Environmental Development. Avaiable: www.ejpau.media.pl/. Accessed 2009 Nov 09.

[20] Gołdyn H (2010) Changes in Plant Species Diversity of Aquatic Ecosystems in the Agricultural Landscape in West Poland in the Last 30 Years. Biodiversity Conserv. 19: 61-80.

[21] Gołdyn H, Arczyńska-Chudy E (2010) Changes of Plant Associations and Their Succession Processes Course in Peat Pits as an Effect of Peat Transformations and the 
Intensification of Meadow Management. In: Szajdak LW, Karabanov AK, editors. Physical, Chemical and Biological Processes in Soils. Poznan: The Committee on Land Reclamation and Agricultural Environment Engineering, Polish Academy of Sciences. pp. 549-559.

[22] Brzeg A, Wojterska M (2001) Plant Communities of Wielkopolska, State of Knowledge and Threats [in Polish]. In: Wojterska M, editor. Plant Cover of Wielkopolska and South Pomerania Lakeland. Guide of Terrain Sessions of 52 PTB Congress. Poznań: Bogucki Wyd. Nauk. pp. 39-110.

[23] Arczyńska-Chudy E (2008) Small Mid-Field Ponds as Biogeochemical Barriers and Phytocenotic Diversity Richness [in Polish]. PhD thesies 199 p.

[24] Ryszkowski L, Karg J (1977) Variability in Biomass of Epigeic Insect in the Agricultural Landscape. Ecol. Pol. 25 (3): 501517.

[25] Karg J (1980) Differentiation of Insect Biomass in Agricultural Landscape. Pol. Ecol. Stud. 6 (2): 317328.

[26] Pollard E (1977) A Method for Assessing Changes in the Abundance of Butterflies. Biol. Cons. 12: 115-134.

[27] Świerzowski A (1973) Influence of Electricity on Fishes and Invertebrates [in Polish]. Roczniki Nauk Rolniczych 95: 141-149.

[28] Rybacki M, Berger L (1997) Amphibians of the General Dezydery Chłapowski Landscape Park [in Polish]. Biuletyn Parków Krajobrazowych Wielkopolski. 2: 22-40.

[29] Rybacki M, Berger L (2003) Contemporary Fauna of Amphibians in Wielkopolska Region in Relation to Disappearance of Their Breeding Sites [in Polish]. In: Banaszak J, editor. Stepowienie Wielkopolski Pół Wieku Później. Bydgoszcz: Wydawnictwo Akademii Bydgoskiej. pp 143-173.

[30] Tomiałojć L (1980) The Combined Version of the Mapping Method. In: Oelke H, editor. Vogelerfassung und Naturschutz. Proc. VI Intern. Conf. Bird Census Work. Göttingen. pp. 92-106.

[31] Bibby CJ, Burgess ND, Hill DA (1992) Bird Census Techniques. London: Academic Press. pp. 257.

[32] Kujawa K (1997) Relationships Between the Structure of Midfield Woods and Their Breeding Bird Communities. Acta Orn. 32: 175-184.

[33] Kujawa K (2006) Effect of Afforestation and Agricultural Landscape Structure on Breeding Bird Communities in Afforestations [in Polish]. Rozprawy Naukowe 381. Poznań: Uniwersytet Przyrodniczy w Poznaniu. 160 pp.

[34] Karg J, Ryszkowski L (1996) Animals in arable land. In: Ryszkowski L, French NR, Kędziora A, editors. Dynamics of an Agricultural Landscape. Poznan: PWRiL, pp. 138172.

[35] Kujawa A, Kujawa K (2008) Effect of Young Midfield Shelterbelts Development on Species Richness of Macrofungi Communities and Their Functional Structure. Pol. J. Ecol. 56: 45-56.

[36] Bałazy S (2003) On Some Little Known Epizootics in Noxious and Beneficial Arthropod Populations Caused by Entomophthoralean Fungi. IOBC-WPRS Bull. 26,1: 63-68. 
[37] Bałazy S (1997) Diversity of Entomopathogenic Fungi in Agricultural Landscape of Poland and France. In: Ryszkowski L, Wicherek S, editors. Ecological Management of Countryside in Poland and France. Poznań: RCAFE PAN. pp. 101-111.

[38] Bałazy S, Miętkiewski R, Tkaczuk C, Wegensteiner R, Wrzosek M (2008) Diversity of Acaropathogenic Fungi in Poland and Other European Countries. Exper. Appl. Acarol. 46,1-4: 53-70.

[39] Bałazy S (in press). 2012. Antagonistic Interactions Between Arthropods and Their Fungous Pathogens in Feeding Sites of Saproxylic Pest Insects [in Polish]. Poznań: Wydawnictwo Uniwersytetu Przyrodniczego.

[40] Zimmermann G (1986) Galleria Bait Method for Detection of Entomopathogenic Fungi in Soil. J. App. Entomol. 2: 213-215.

[41] Strasser H, Forrer A, Schinner F (1996) Development of Media for the Selective Isolation and Maintenance of Virulence of Beauveria brongniartii In: Jackson TA, Glare TR, editors. Microbial Control of Soil Dwelling Pests. Lincoln: AgResearch. pp. 125-130.

[42] DAISIE - 100 of the worst [Internet]. Available: http://www.europealiens.org/speciesTheWorst.do

[43] Kaźmierczakowa R, Zarzycki K (editors) (2001) Polish Red Book of Plants. Pteridophytes and Flowering Plants [in Polish]. Kraków: PAS, W. Szafer Institute of Botany, Institute of Nature Conservation. 664 p.

[44] Szyszkiewicz-Golis M., 2001, Land use changes and the structure of agricultural landscape in the Wielkopolska Region-western part of the Row Wyskoc catchment. The Problems of Landscape Ecology - volume X: Transformations of the natural environment of Poland and its functioning. Institute of Geography and Spatial Management of Jagiellonian University and Polish Association for Landscape Ecology, Krakow, 92-99 [In Polish]

[45] Ryszkowski L, Karg J, Kujawa K (1999) Protection and Management of Biodiversity in Agricultural Landscape [in Polish]. In: Ryszkowski L, Bałazy S, editors. Uwarunkowania Ochrony Różnorodności Biologicznej i Krajobrazowej. Zakład Badań Środowiska Rolniczego i Leśnego PAN. Poznań: pp. 59-80.

[46] Wasilewska L (1979) The Structure and Function of Soil Nematode Communities in Natural Ecosystems and Agrocenoses. Pol. Ecol. Stud. 5: 97-145.

[47] Kasprzak K, Ryl B (1978) The Influence of Agriculture on the Occurrence of Oligochaeta in Arable Soils [in Polish]. Wiadomości Ekologiczne. 24: 333-366.

[48] Ryl B (1984) Comparison of Communities of Earthworms (Lumbricidae) Occurring in Different Ecosystems of Agricultural Landscape. Ekol. Pol. 32: 155-165.

[49] Wolak M, Karg J (2002) Spiders Wintering in Mid-field Wooded Patches [in Polish]. In: Banaszak J, editor. Wyspy Środowiskowe. Bioróżnorodność i Próby Typologii: Wyd. Akademii Bydgoskiej. pp. 147-158.

[50] Kajak A, Oleszczuk M (2004) Effect of Shelterbelts on Adjoining Cultivated Fields: Patrolling Intensity of Carabid Beetles (Carabidae) and Spiders (Araneae). Pol. J. Ecol. 52 (2): 155-172.

[51] Mielewczyk S. Qualitative and Quantitative Changes in Occurrence of Ephemeroptera, Odonata, Heteroptera and Coleoptera in Young Mid-field Pond [in Polish]. In: Mat. Zjazdowe XVII Zjazdu Hydrobiologów Polskich. 1997 wrzesień 8-11; Poznań: 96. 
[52] Banaszak J (1983) Ecology of Bees (Apoidea) of Agricultural Landscape. Pol. Ecol. Stud. 9: 421-505.

[53] Szeflińska D (1997) Thrips (Thysanoptera) of Grassland Habitats in the General Dezydery Chłapowski Landscape Park [in Polish]. Biuletyn Parków Krajobrazowych Wielkopolski. 2 (4): 72-77.

[54] Szeflińska D (2002) Thysanoptera of Cereals in Central Wielkopolska. Bulletin of the Polish Academy of Sciences. 50 (3): 177-181.

[55] Oleszczuk M (2010) Refugial Areas in Farmland as Habitats for Rarely Found and Threatened Species of Spiders (Araneae) in Poland [in Polish]. Chrońmy Przyr. Ojcz. 66: 361-374.

[56] Oleszczuk M (2011) Plant-dwelling Spiders (Araneae) of Selected Habitats in Manor Park in Turew [in Polish]. Biuletyn Parków Krajobrazowych Wielkopolski 19: 98-103.

[57] Berger L, Rybacki M (1999) Composition and Ecology of Water Frog Populations in Agricultural Landscape in Wielkopolska. Biological Bulletin of Poznań. Zoology 35(2): 103-111.

[58] Kujawa K (2000) Avifauna of the General Dezydery Chłapowski Landscape Park [in Polish]. Wielkopolskie Prace Ornitologiczne 9:89-121.

[59] Kujawa K (1996) The Influence of Agricultural Landscape Structure on Breeding Avifauna [in Polish]. PhD Thesis. University of Wrocław.

[60] Kujawa K, Łęcki R (2008) Does Red Fox Vulpes vulpes Affect Bird Species Richness and Abundance in an Agricultural Landscape? Acta Orn. 43:167-178.

[61] Ryszkowski L (1982) Structure and Function of the Mammal Community in an Agricultural Landscape. Acta Zool. Fenn. 169: 45-59.

[62] Kozakiewicz M (1993) Habitat Isolation and Ecological Barriers - the Effect on Small Mammal Populations and Communities. Acta Theriol. 38: 1-30.

[63] Kozakiewicz M, Jurasińska E (1989) The Role of Habitat Barriers in Woodlot Recolonization by Small Mammals. Holarctic Ecol. 12: 106-111.

[64] Hansson L (1987) Dispersal Routes of Small Mammals at an Abandoned Field in Central Sweden. Hol. Ecol. 10: 154-159.

[65] Yahner RH (1983) Small Mammals in Farmstead Shelterbelts: Habitat Correlates of Seasonal Abundance and Community Structure. J. Wildl. Manage. 47: 74-84.

[66] Rozporządzenie Ministra Środowiska z dnia 9 lipca 2004 r. w sprawie gatunków dziko występujących grzybów objętych ochroną. Dz.U. 04.168.1765 z dnia 28 lipca 2004 r.

[67] Wojewoda W, Ławrynowicz M (2006) Red List of the Macrofungi in Poland. In: Mirek Z, Zarzycki K, Wojewoda W, Szeląg Z, editors. Red List of Plants and Fungi in Poland. 3rd ed. Kraków: W. Szafer Institute of Botany, Polish Academy of Sciences. pp. 53-70.

[68] Wojewoda W (2003) Checklist of Polish Larger Basidiomycetes. In: Mirek Z, editor. Biodiversity of Poland. Vol. 7. Kraków: W. Szafer Institute of Botany, Polish Academy of Sciences. pp. 1-812.

[69] Chmiel MA (2006) Checklist of Polish Larger Ascomycetes. In: Mirek Z, editor. Biodiversity of Poland. Vol. 8. Kraków: W. Szafer Institute of Botany, Polish Academy of Sciences. pp. 1-152. 
[70] Mułenko W, Majewski T, Ruszkiewicz-Michalska M (2008), editors. A Preliminary Checklist of Micromycetes in Poland. In: Mirek Z, editor. Biodiversity of Poland. Vol. 9. Kraków: W. Szafer Institute of Botany, Polish Academy of Sciences. pp. 1-752.

[71] Karg J, Bałazy S (2009). Effect of Landscape Structure on the Occurrence of Agrophagous Pests and Their Antagonists [in Polish]. Progress in Plant Protection 49, 3: 1015-1034.

[72] Tkaczuk C (2008) Occurrence and Infectious Potential of Entomopathogenic Fungi of Soils in Agrocenoses and Semi-natural Habitats in an Agricultural Landscape [in Polish]. Rozprawy naukowe 94. Siedlce: Wyd. Akademii Podlaskiej. 160 p.

[73] Kujawa A, Gołdyn H, Arczyńska-Chudy E (2005) A New Locality of Daisy Leaf Grape Fern (Botrychium matricariifolium) in Western Poland. Rocz. AR Pozn. 372, Bot-Stec. 8: 129-132.

[74] Zając M, Zając A, Tokarska-Guzik B (2009) Extinct and Endangered Archaeophytes and the Dynamics of their Diversity in Poland. Biodiv. Res. Conserv. 13: 17-24.

[75] Żukowski W, Jackowiak B (1995) List of Endangered and Threatened Vascular Plants in Western Pomerania and Wielkopolska (Great Poland). In: Żukowski W, Jackowiak B, editors. Endangered and Threatened Vascular Plants of Western Pomerania and Wielkopolska. Publications of the Department of Plant Taxonomy of the Adam Mickiewicz University in Poznań. Poznań: Bogucki Wyd. Nauk. pp. 9-96.

[76] Ratyńska H (2003) Plant Cover as a Result of Anthropogenic Changes in Landscape Exemplified by the River Główna Catchment Area (the middle Wielkopolska Province, Poland) [in Polish]. Bydgoszcz: Wyd. Akademii Bydgoskiej im. Kazimierza Wielkiego. $381 \mathrm{p}$.

[77] Pliński M (2009) Dangerous Water Blooms - Not Only a Hydrobiological Problem.XXI Congress of the Polish Hydrobiologist, Lublin, 9-12 Sep 2009. Session V- Ecotoxicology waters. p. 5 .

[78] Mazur-Marzec H (2011) Toxic Blooms of Cyanobacteria in the Baltic Sea and Their Impact on Human Health. WWF Report Poland.

[79] Burchardt L, Pawlik-Skowrońska B (2005) Blue-Green Algal Blooms-Interspecific Competition and Environmental Threat. Wiad. Bot. 49: 39-49.

[80] Wilcox TP, Hornbach DJ (1991) Macrobenthic Community Response to Carp (Cyprinus carpio L.) Foraging. J. Freshwat. Ecol. 6: 170-183.

[81] Gehrke PC, Harris JH (1994) The Role of Fish in Cyanobacterial Blooms in Australia. Aust. J. Mar. Fresk. Res. 45: 905-15.

[82] Breukelaret AW, Lammens EH, Breteler K (1994) Effects of Benthivorous Bream (Aramis brama) and Carp (Cyprinus Carpio) on Sediment Re-Suspension and Concentrations of Nutrients and Chlorophyll a. Freshw. Biol. 32: 113-121.

[83] Williams AE, Moss W, Eaton J (2002) Fish Induced Macrophyte Loss in Shallow Lakes: Top-down and Bottom-up Processes in Mesocosm Experiments. Freshw. Biol. 47: 2216 2232.

[84] Karg J (2004) Importance of Midfield Shelterbelts for Over-wintering Entomofauna (Turew area, West Poland). Pol. J. Ecol. 52 (4): 421-431. 
[85] Ryszkowski L, Karg J, Glura M (2009) Influence of Agricultural Landscape Structure on Diversity of Insect Communities. Pol. J. Ecol. 57 (4): 697 - 713.

[86] Tryjanowski P, Kuźniak S, Kujawa K, Jerzak L (2009) Ecology of Farmland Birds [in Polish]. Poznań: Bogucki Wyd. Nauk. 390 p.

[87] Pugacewicz E (2000) Breeding Avifauna of an Agricultural Landscape in Bielska Plain [in Polish]. Not. Ornitol. 41:1-28.

[88] Kujawa K, Tryjanowski P (2000) Relationships Between the Abundance of Breeding Birds in Western Poland and the Structure of Agricultural Landscape. Acta Zool. Hung. 46: 103-114.

[89] Kujawa K (1996a) The Influence of Landscape Pattern on Breeding Bird Communities in D. Chlapowski Landscape Park [in Polish]. Biuletyn Parków Krajobrazowych 3: 83-90.

[90] Kujawa K (2002) Population Density and Species Composition Changes for Breeding Bird Species in Farmland Woodlots in Western Poland Between 1964 and 1994. Agric. Ecosyst. Environ. 91: 261-271.

[91] Kujawa K (2008a) Long Term Changes (1964-2006) in Breeding Bird Community of Midfield Afforestations in the Dezydery Chłapowski Landscape Park (Wielkopolska) [in Polish]. In: Kaczmarek S, editor. Krajobraz i bioróżnorodność. Bydgoszcz: Wyd. Uczel. UKW. pp. 151-167.

[92] Sosa-Gomez DR, Delpin KE, Moscardi F, Farias JRB (2001) Natural Occurrence of the Entomopathogenic Fungi Metarhizium, Beauveria and Paecilomyces in Soybean Under Till and No-till Cultivation Systems. Neotrop. Entomol. 30,1: 407-410.

[93] Hummel RL, Walgenbach JF, Barbercheck ME, Kennedy GG, Hoyt GD, Arellano C (2002) Effects of Production Practices on Soil-Borne Entomopathogens in Western North Carolina Vegetable Systems. Environ. Entomol. 31: 84-91.

[94] Root TL, Price JT, Hall KR, Schneider SH, Rosenzweig C, Pounds JA (2003) Fingerprints of Global Warming on Wild Animals and Plants. Nature 421: 57-60.

[95] Ryszkowski L (1990) Agricultural Landscape of Turew Vicinity [in Polish]. In: Ryszkowski L, Marcinek J, Kędziora A, editors. Obieg Wody i Bariery Biogeochemiczne w Krajobrazie Rolniczym. Poznań: Wydawnictwo UAM. pp. 5-12.

[96] Ryszkowski L, Kędziora A (2007) Sustainability and Multifunctionality of Agricultural Landscapes. In: Plieninger T, editor. Zukunftsorientierte Nutzung Ländlicher Räume Land Innovation. Materialien 15. Berlin-Brandenburgische Akademie der Wissenschaften, Berlin: pp. 5 23..

[97] Herk CM, Aptroot A, Dobber HF (2002) Long-term Monitoring in the Netherlands Suggests that Lichens Respond to Global Warming. Lichenologist 34: 1-15.

[98] Kreisel H (2006) Global Warming and Mycoflora in the Baltic Region. Acta Mycol. 41:79-94.

[99] Emanuel WR, Shugart HH, Stevenson MP (1985) Climate Change and the Broad Scale Distribution of Terrestial Ecosystem Complexes. Climatic Change 7: 29-43.

[100] Notaro M, Vavrus S, Liu Z (2007) Global Vegetation and Climate Change due to Future Increases in $\mathrm{CO} 2$ as Projected by a Fully Coupled Model with Dynamic Vegetation. J. Climate 20: 70-90. 
[101] White P, Kerr JT (2006) Contrasting Spatial and Temporal Global Change Impacts on Butterfly Species Richness During the 20th Century. Ecography 29: 908918.

[102] Kerbiriou C, Le Viol I, Jiguet F, Devictor V (2009) More Species, Fewer Specialists: 100 years of Changes in Community Composition in an Island Biogeographical Study. Diversity Distrib. 15: 641-648.

[103] Benning TL, LaPointe D, Atkinson CT, Vitousek PM (2002) Interactions of Climate Change with Biological Invasions and Land Use in the Hawaiian Islands: Modeling the Fate of Endemic Birds Using a Geographic Information System. Proc. Nat. Acad. Sc. J. 29: 14246-14249.

[104] Isaac JL (2009) Effects of Climate Change on Life History: Implications for Extinction Risk in Mammals. Endang. Species. Res. 7: 115-123.

[105] Malcolm JR, Liu C, Neilson RP, Hansen L, Hannah L (2006) Global Warming and Extinctions of Endemic Species from Biodiversity Hotspots. Conserv. Biol. 20: 538548.

[106] Davey CM, Chamberlain DE, Newson SE, Noble DG, Johnston A (2011) Rise of the Generalists: Evidence for Climate Driven Homogenization in Avian Communities. Global Ecology and Biogeography 21: 568-578.

[107] Pounds JA, Bustamente MR, Coloma LA, Consuegra JA, Fogden MPL, et al. (2006) Widespread Amphibian Extinctions from Epidemic Disease Driven by Global Warming. Nature 439: 161-67.

[108] Deschka G, Dimic N (1986) Cameraria ohridella n. sp. aus Mazedonien, Jugoslawien (Lepidoptera, Lithocelletidae). Acta Ent. Jugosl. 22: 11-23.

[109] Łabanowski G, Soika G (1998) The Horse Chestnut Leafminer Infesting Chestnut in Poland. Ochrona Roślin. 42(12): 12.

[110] Gifford RM (1977) Growth Pattern, Carbon Dioxide Exchange and Dry Weight Distribution in Wheat Growing Under Differing Photosynthetic Environments. Aust. Jour. Plant Physiol. 4: 99-110.

[111] Sionit N, Morten DA, Strain BR, Helmers H (1981) Growth Response of Wheat to $\mathrm{CO}_{2}$ Enrichment and Different Levels of Mineral Nutrition. Agr. Jour. 73: 1023-1027.

[112] Rogers HH, Thomas JF, Bingham GE (1983) Response of Agronomic and Forest Species to Elevated Atmospheric Carbon Dioxide. Science 220: 428429.

[113] Kimball BA, Kobayashi K, Bindi M (2002) Responses of Agricultural Crops to Free-air CO2 Enrichment. Adv. Agron. 77: 293-368.

[114] Emmerich WE (2007) Ecosystem Water Use Efficiency in a Semiarid Shrubland and Grassland Community. Rangeland Ecol. Manage. 60: 464-470.

[115] Chylarecki P, Jawińska D, Kuczyński (2006) Monitoring of Common Breeding Birds Report from Years 2003-2004. Warszawa: OTOP.

[116] Fog K (1988) Reinvestigation of 1300 Amphibian Localities recorded in the 1940s. Memoranda Soc. Fauna Flora Fennica 64: 134-135.

[117] Fog K (1997) A survey of the results of pond projects for rare Amphibians in Denmark. Memoranda Soc. Fauna Flora Fennica.73: 91-100.

[118] Stasiak P (1991) Disappearance of Small Mid-field Water Bodies in Wielkopolska Lowland in the Light of Cartographic Materials [in Polish]. M.Sc. Thesis. Adam Mickiewicz University, Poznań. 